This is a self-archived version of an original article. This version may differ from the original in pagination and typographic details.

Author(s): Stucki, Tobias; Wochner, Daniel

Title: Technological and organizational capital : Where complementarities exist

Year: 2019

Version: Accepted version (Final draft)

Copyright: (c) 2018 Wiley Periodicals, Inc.

Rights: In Copyright

Rights url: http://rightsstatements.org/page//nC/1.0/?language=en

Please cite the original version:

Stucki, T., \& Wochner, D. (2019). Technological and organizational capital : Where complementarities exist. Journal of Economics and Management Strategy, 28(3), 458-487.

https://doi.org/10.1111/jems.12269 


\title{
Technological and Organizational Capital: Where Complementarities Exist
}

\author{
Tobias Stucki*, Daniel Wochner**
}

Draft version. Final version forthcoming in Journal of Economics \& Management Strategy

\begin{abstract}
This study analyzes the complementarities between technological and organizational capital within enterprises. Different components of technological and organizational capital exert distinct — and often opposed — forces on each other. Our empirical results show that whereas greater employee voice promotes firm productivity when combined with information technology, it harms firm productivity when combined with communication technology. On the other hand, flexible work design is positively associated with communication technology and negatively associated with information technology.
\end{abstract}

Acknowledgments: This article has greatly benefited from the guidance of the Editor, Daniel Spulber, and the valuable comments and suggestions of two anonymous reviewers of this journal. Moreover, we would like to thank Nicholas Bloom, Michael Pfaffermayr, John Roberts and Jan-Egbert Sturm for many helpful comments and discussions.

Keywords: Information and communication technologies, organization, complementarity, organizational performance, firm productivity

JEL classification: D23, O31, O32, O33

* University of Jyväskylä, Finland; tobias.m.stucki@jyu.fi

** ETH Zurich, KOF Swiss Economic Institute, Switzerland; wochner@kof.ethz.ch 


\section{INTRODUCTION}

“The digitization of just about everything — documents, news, music, photos, video, maps, personal updates, social networks, request for information and responses to those requests, data from all kind of sensors, and so on — is one of the most important phenomena of recent years.” (Brynjolfsson \& McAfee, 2014, p. 66). Just as important as digitization is, so imperative is a better understanding of the impact of digital technologies on productivity and growth to allow academics, business executives and policy makers to foster policy landscapes that embrace the power of these technologies and seize the digital opportunity (Crespi, Criscuolo, \& Haskel, 2007; Brynjolfsson \& Saunders, 2010).

It comes therefore with only little surprise that a large literature aimed at examining the productivity effects of investments in information and communication technologies. ${ }^{1}$ Surprisingly, however, initial investigations two decades ago struggled to find any measurable contributions of ICT investments to productivity growth (Loveman, 1994; Solow, 1987; Strassmann, 1990) - a conundrum coined the 'Productivity Paradox’. While researchers were initially concerned with ICT’s direct role as a production technology to improve productivity, more recent work referred to ICT’s role as a coordination technology and carefully addressed its indirect linkages to productivity (Dedrick et al., 2003). These studies resort to organizational complementarity theory based on seminal work by Milgrom and Roberts $(1990,1995)$ who pointed to the beneficial and complex interplay of technology with human capital and different organizational practices, structures and processes (often termed 'organizational capital') to yield benefits over and above the effects each element could generate on its own. Thus, even if the direct productivity effects of ICT per se might be low - as observed in the initial investigations - its effect is expected to increase, when combined with adequate organizational practices. Indeed, the empirical evidence for the complementarity hypothesis substantiates and some studies find a significant larger contribution from ICT investments, when they are combined with new organizational practices (see Brynjolfsson \& Milgrom, 2013 for a comprehensive review).

\footnotetext{
${ }^{1}$ For an overview of this literature see Biagi (2013), Draca et al. (2006) or Van Reenen et al. (2010).
} 
In the recent past, the discussion around ICT use and its effects for organizational performance has progressed quite a bit. In the Information System literature, for example, Nevo and Wade (2010) have developed a theory that holds that information technology assets can become sources of competitive advantage if they are combined with proper organizational resources. However, identifying complementarities is a complex issue as combining organizational and technological capital not always stimulates economic outcome. For example, both centralized and decentralized decision rights can be valuable if they are supported with the right technology (Tiwana 2015). But what is the right technology? The relevant question to be answered is therefore which combinations of organizational and technological capital lead to synergies.

Previous studies on the complementary relationship between technological and organizational capital mostly use composite measures of both technological capital and organizational capital (e.g., Brynjolfsson et al., 2002; Bresnahan et al., 2002). Hence, they do not distinguish between different types of technological and organizational capital. Another strand of the literature focuses on very specific types of technological or organizational capital (e.g., Chwelos et al., 2010; Tiwana, 2015), which also makes it difficult to get an overall picture of where synergies exist and where not. By distinguishing among two different technology types (information technology (IT) and communication technology (CT)) and three different forms of organizational capital (employee voice, work design and workforce training), the goal of this study is to adopt a more nuanced analysis by examining complementarities among different components of technological and organizational capital (see Figure 1). Concretely, we thus test whether IT and CT, respectively, stimulate or hamper the effect of employee voice, work design, and workforce training. We thereby aim to better understand what role different technologies play for optimal organizational designs and aim to shed more light on how businesses may direct their technology investments most productively. Probably most related to this study, Bloom et al. (2014) find that IT is related to a higher degree of decision autonomy and a greater span of control, whereas CT decreases autonomy. However, it remains unclear whether IT also stimulates other components of 
organizational capital, and whether CT generally hampers the effect of organizational capital. In this paper, we predict that this is not the case.

Our analyses are based on data from four waves of the KOF Innovation Survey covering a representative sample of Swiss firms in the years 2002, 2005, 2008, and 2011. We adopt a performance differences approach (Brynjolfsson and Milgrom, 2013) and examine the impacts of adopting different types of ICT and organization on productivity outcomes in productivity regressions. As these surveys include information on firm productivity, many different components of workplace organization, ICT use, as well as other potential drivers of firm productivity, an important advantage of this data is that complementarities between ICT and organizational capital can be analyzed in greater detail than previous studies were able to. Furthermore, as the data spans a period of almost ten years, we have enough within-firm variation in order to control for unobserved time invariant firm fixed effects, which allows us to significantly reduce a potential omitted variable bias problem.

In line with our expectations, we find that IT and CT exert distinct — and often opposed — forces on the optimal degree of employee voice, work design and workforce training. Moreover, as the moderating effects of IT and CT with organizational capital countervail each other, we observe rather weak complementarities between organizational capital and ICT in general. In sum, the results thus clearly confirm our prediction that a disaggregated analysis is required in order to properly identify complementarities between technological and organizational capital.

\section{CONCEPTUAL FRAMEWORK AND HYPOTHESES}

Beyond the traditional forms of capital, such as labor and physical capital, economists increasingly acknowledge the importance of new types of production factors: In particular, the emergence and rise of vast investments into ICT has led an asset coined 'technological capital' or 'ICT capital' to distinguish these productive investments from more traditional ones in non-ICT capital (Arvanitis \& Loukis, 2009). Moreover, there is a general tendency in shifting from old, Tayloristic to modern, holistic organizations, which are reliant on new work practices such as continuous learning, increased worker autonomy and higher decentralization (Lindbeck \& Snower, 2000). The case study literature points to leading examples 
from different industries such as Lincoln Electric, Walmart, Dell or Google (see Brynjolfsson \& Saunders, 2010). These firms have all heavily and deliberately invested in these new organizational practices and developed and accumulated an asset frequently termed 'organizational capital'. The conceptual framework put forth in the following takes a careful look at the component parts of these new types of capital and examines their synergetic interactions.

\subsection{Components of technological and organizational capital}

\section{Technological capital}

An overwhelming body of researchers treated ICT as a single, aggregated technological capital stock when examining their economic impacts. However, such a non-differentiated, aggregated ICT-

perspective can be disputed, and IT and CT should be analysed separately (Bloom et al., 2014; Garicano, 2000). We propose to maintain this crucial distinction between IT and CT when examining complementary organizational interactions. We distinguish the two along their functional rather than their formal dimension because it matters to workers what they can do with these technologies, and less so how the technologies are formally set up (Schienstock et al., 2002). Moreover, focusing on their functional rather than formal nature appears to be more sensible because their technical characteristics and capabilities usually change rapidly whereas their functional objectives and use cases do less so.

Hence, we understand IT as the computer hardware and software which is primarily used as an information processing device to (i) collect and, analyze information, (ii) automate and improve work processes or (iii) to monitor and control work behavior or production processes (cf. Schienstock et al., 2002; Huang et al. 2012). While many information-processing activities can be directly performed on local information systems, CTs instead always rely on a network infrastructure and connectivity that links different information systems together to become productive. They are primarily used as information flow and knowledge exchange devices to (i) distribute, transmit and communicate information or (ii) to coordinate temporally and spatially distributed activities (cf. Schienstock et al., 2002; Huang et al. 2012). Beyond other telecommunication technologies (such as telephone, fax, mail, 
internet, video conferencing or electronic data interchange), the introduction of corporate intranets was, for instance, a notable technological innovation affecting the communication, sharing and distribution of documentation within firms.

\section{Organizational capital}

The conceptualization of organizational capital is a burgeoning research area in economics and there has not yet emerged a general consensus on its definition, but it is probably best understood as the value of intangible and non-tradable stock of organizational practices, processes and structures both within and between firms (Brynjolfsson \& Saunders, 2010). The literature praised not more than a handful of attempts that approach the notion of organizational capital systematically and we draw on a comprehensive taxonomy provided by Black and Lynch (2005). They proposed to comprise organizational capital within any organization into three different categories: employee voice, work design and workforce training, each of which was shown to be productivity enhancing both theoretically and empirically. Black and Lynch (2005) argue that these three components of organizational capital are a comprehensive but not an exhaustive list of all possible elements. The role of further components of organizational capital, such as e.g. firm structure or incentive pay schemes will be discussed in an extension to the main model (see Section 5.2).

The first element 'employee voice’ includes organizational structures that provide workers, especially lower level production workers, with more decision power to contribute towards the design production processes and a higher degree of autonomy to structure their own work. Examples range from individual or collective employee consultation, to decentralized decision competencies and selfmanaged teams to individual job-enrichment schemes (ibid., p. 207). Second, 'work design' embraces the creation and development of organizational practices and processes that enable a more flexible reallocation of labor within the firm. Examples include efforts to change the firm’s occupational structures, adapting the number of hierarchies, investing into diverse and cross-functional teams or expanding job rotation and job sharing agreements (ibid., p. 207 f.). Finally, the third component of 
organizational capital is 'workforce training'. The human capital literature usually distinguishes training from education. While education obtained at academic institutions is most often of purely general human capital and equally valuable to all potential employers, training instead is most often firmspecific and thus most valuable to the current employer (Lazear \& Gibbs, 2008). As a consequence, the worker and the firm jointly determine the investment in additional skills, which are particularly valuable within the context of the organization. Hence, while both education and training contribute to firm productivity, workforce training constitutes an important component that contributes toward organizational capital (Black \& Lynch, 2005, p. 206 f.).

\subsection{Complementarity hypotheses between individual components of technological and organizational capital}

The literature on complementarities between technological and organizational capital goes back to work of Milgrom and Roberts (1990, 1995), which pointed to the complex and beneficial interplay of technology and organizational practices to yield synergetic benefits over and above the effects that each element could generate on its own. Simply put, a certain degree of fit or match among the organizational practices and technologies in place is required to achieve superior performance (Zand et al., 2011).

Among those studies that investigated the complementarity between technological capital and organizational capital on firm productivity, two different kinds of perspectives were adopted (see Figure 1): Most often, these complementarities were examined from an aggregate perspective by using broad conceptual measures and composite indicators for both technological and organizational capital. A fewer set of studies adopted a differentiated perspective but focused on complementarities of single components of technological and organizational capital in isolation (e.g., only between training and ICT). This, however, leaves the complementary nature of technological and organizational capital incompletely understood.

The goal of this research is to adopt a differentiated, disaggregated perspective to pursue a more nuanced analysis by examining complementarities among the previously discussed individual 
components of technological and organizational capital. By distinguishing among two different technology types (IT and CT) and three different forms of organizational capital (employee voice (EV), work design (WD) and workforce training (WT)), there is a large number of potential complementarities to investigate: not only between the two types of capital considered but also among the different components within each type (see Figure 1). While we do not neglect the potential importance of withinfactor complementarities, our analyses suggest that they are of second order importance, as e.g. the different components of organizational capital appear to be largely orthogonal to one another (see Table A.9). Hence, we focus on between-factor complementarities and draw on most recent theoretical contributions to substantiate our hypotheses.

\section{Complementarities with employee voice}

Employee voice measures the degree of employee involvement and real decision power to the production process and may therefore be considered as an organizational asset measuring the degree of decentralized decision making authority.

The literature put forth a comprehensive amount of research on the complementarity between technology and the allocation of decision rights (see Hitt \& Brynjolfsson (1997), Caroli \& Van Reenen (2001); Bresnahan et al. (2002); Bloom, Sadun, Van Reenen (2012)). The role that digital technologies play for decision authority, however, is still heavily disputed: While some argued that technology should be associated with more centralization, others gave reasons for more decentralization, still others asserted even no association at all. $^{2}$

\footnotetext{
${ }^{2}$ One stream of the literature argues that investments in ICT should increase tendencies towards decentralization if knowledge is local and resides at the periphery of the firm (Hitt \& Brynjolfsson, 1997; Malone, 1997; McElheran, 2014), if adaption to local conditions is more important than coordination (McElheran, 2014), when managers are boundedly rational and have a limited information processing capacity to deal with ICT-led information overflows (Bolton \& Dewatripont, 1994; Van Zandt 1999) or, as agency theorists emphasize, when better monitoring abilities and performance measures are available (Gurbaxani \& Whang, 1991; Malone, 1997). On the other hand, ICTs may also increase centralization if coordination of technology investments is more important than adaption (McElheran, 2014), and if, to mention agency-based concerns, ICT reduces the local information advantages of workers due to the availability of more, faster and better information to management (Whisler \& Levitt, 1958; Gurbaxani \& Whang, 1991). Yet other contributions asserted even no association at all (cf. Malone, 1997).
} 
Bloom et al. (2014) have most recently argued that lumping together different kinds of technologies may fall short of the mark. Instead, a more careful analysis of differential types of technology is required to disentangle the effects of technology on decision authority and thereby proposed a possible solution to some long-standing debates in the literature. In particular, they have shown both theoretically in a team-theoretic framework and empirically across a number of industries and countries that the effects of IT and CT on a firm's (de-)centralization decision (and thus on productivity and inequality, see Garicano \& Rossi-Hansberg, 2015) may differ greatly. They resort to theories of the organization of knowledge within firms by Garicano (2000) and Garicano and Rossi-Hansberg (2006) to make the key distinction between IT and CT on theoretical grounds. As they argue, production requires problem solving and decision making with the relevant knowledge for these decisions, which can either be obtained through the acquisition or the communication of information. This implies that firms determining the hierarchical level at which the organization's decisions should be taken, ultimately face a trade-off between information acquisition and communication costs. ${ }^{3}$ Advanced ITs (such as EnterpriseResource-Planning, CAD or CAM systems) allow for a cheaper access to more and better information and make it more efficient to acquire the relevant knowledge, which in turn allows workers to take more decisions without any direct consultation of their managers. As a result, ITs push decisions ‘down' and favor a more decentralized decision regime. By contrast, decreased communication costs due to better CTs make asking cheaper than learning and, in consequence, make consultation of their superiors more efficient for workers than acquiring the necessary knowledge themselves. As a result, better CTs favor more centralized decision-making and push decisions ‘up’ (Bloom et al., 2014). ${ }^{4}$

\footnotetext{
${ }^{3}$ Garicano (2000) argues that expertise is organized hierarchically if problems are complex. He shows that knowledge-based hierarchies are the most efficient organizational outcome when the matching of problems to people with the necessary knowledge (of how to solve them) is hard, such as e.g. in situations where knowledge is completely tacit. In this case, specialists with non-overlapping knowledge cannot communicate and would incur too high search costs to find the relevant knowledge. Asking for help can only take the form of vertical communication: people with overlapping and superior knowledge can identify the solution (see also Garicano \& Wu, 2012, Section 4.2 for an elaborate discussion).

${ }^{4}$ To examine the possibility of alternative theoretical explanations, they also tested the technologies' impacts on coordination costs in the absence of incentive conflicts, their impacts on delegation through reduction of information asymmetries as well as the impact of automation and showed that none of these explanations is driving their results.
} 
For these reasons, we consider advanced ITs and employee voice to interact in a complementary and mutually reinforcing way and expect a positive interactive productivity impact. By contrast, advances in CTs are expected to unleash tendencies towards centralization where the worker's knowledge and decisions are substituted by their managers. Hence, CTs are expected to interfere with higher degrees of employee voice and should therefore feature a negative interactive effect upon productivity.

\section{Complementarities with work design}

Inspired by Atkinson (1984)'s core-periphery model, the literature distinguishes between two different types of labor flexibility, numerical (external) and functional (internal) flexibility. The former refers to strategies to flexibly adjust the quantity of workers via temporaries, independent contractors or subcontractors. The latter is characterized by a low division of work and refers to practices that broaden workers’ competences by means of less specialized job-assignments and increased job rotation, teamwork, multi-skilling or multi-tasking to enable a more flexible (re-)allocation of labor within the firm (see e.g. Arvanitis, 2005; Martinez-Sanchez et al., 2011; Voudouris, 2007). Work design, as the term is understood here, refers to the concept of functional flexibility. ${ }^{5}$

While empirical studies generally find support for the complementarity hypotheses between technology and functional flexibility (see e.g. Osterman, 1994 and Black \& Lynch 2004 for the United States; Caroli \& Van Reenen, 2001, for France and Britain; Bertschek \& Kaiser, 2005 for Germany; Arvanitis, 2005, for Switzerland; Voudouris, 2007, for Greece; Martinez-Sanchez et al., 2011, for Spain), the theoretical literature has not yet reached widespread agreement about the impacts of technological advances (see e.g. Becker \& Murphy, 1992; Bolton \& Dewatripont, 1994; Lindbeck \& Snower, 2000; Dessein \& Santos, 2006). In fact, there are only relatively few models that are able to

\footnotetext{
${ }^{5}$ While employee voice refers to vertical allocation of decision authority, work design can be understood as the horizontal allocation of decision authority over various tasks (cf. Bolton \& Dewatripont, 2013)
} 
explain the rise of flexible work designs in light of better information and communication technologies (Autor, 2012; Snower \& Görlich, 2013).

An interesting starting point to examine the differential impacts of IT and CT on work design is provided in a renowned theoretical framework by Lindbeck and Snower (2000) who explained how technological advances, among other forces, shift organizations towards more flexible work designs. Boucekkine and Crifo (2008) have more recently advanced their static framework into a dynamic model with an endogenous human capital formation and were able to replicate some of the stylized facts on both work organization and job contents as observed in many OECD countries, including work by Autor, Levy and Murnane, (2002, 2003) and further empirical studies cited above.

Building upon these contributions, it proves helpful to distinguish between the two ends of a continuum of flexibility degrees à la Lindbeck and Snower (2000): An organization with a low level of functional flexibility relies on task specialization and intra-task learning (the skill acquisition on one particular task over time) and reaps the returns from specialization due to scale economies. In contrast, high degrees of functional flexibility emphasize task complementarities and inter-task learning (the acquisition of skills on one tasks and their reemployment on other tasks) to earn the returns from multitasking due to scope economies.

Accordingly, a firm determining the degree of functional flexibility faces a trade-off between returns from (task-)specialization and multitasking. Boucekkine and Crifo (2008) have shown that the relative size of these returns determines one of two globally stable steady-state equilibrium regimes of work design: A Tayloristic regime (emphasizing specialization) and a holistic regime (emphasizing multitasking). We argue, much in line with Boucekkine and Crifo (2008), that IT and CT exert distinct forces on the returns from specialization versus multitasking and therefore on the optimal degree of functional flexibility. ${ }^{6}$

\footnotetext{
${ }^{6}$ Boucekkine and Crifo (2008) argue in more general terms about ICT and do not explicitly distinguish between IT and CT but they implicitly highlight the functional roles of IT and CT as defined in this article.
} 
Technological advances over the past decades were hallmarked by computer-mediated massproduction, programmable machines and automated sensory tools. These advances in IT have accentuated the returns from specialization by improving production speed, accuracy and scalability and provided employees with faster access to more and better information, which increased the overall productivity in performing a particular task. Bartel, Ichniowsky and Shaw (2007) show how ITenhanced machinery translates into reduced production times and improved efficiency in all stages of production processes. Further prominent examples include the automotive industry with its standardized assembly lines for mass production as popularized by Henry Ford, which enabled car manufacturers to reap increased returns from task specialization and resulted in a widespread increase in the division of labor (cf. Boucekkine \& Crifo, 2008; Lindbeck \& Snower, 2000, provide similar examples). These exemplary shifts in the division of labor are not peculiar to car manufacturers; rather all mass producers of consumer goods worldwide adopted some of Ford’s basic principles (Dankbaar, 1997). Similarly, Autor et al. (2002) provide evidence for the service sector, where the introduction of information processing technologies in banking, such as digital imaging of bank checks and optical character recognition software, has led to more specialized jobs and an increase in average labor productivity in one of the two departments examined.

In sum, advances in IT are thus expected to increase returns from specialization, which - according to the Boucekkine-Crifo model - induces profit-maximizing firms to transition towards a Tayloristic regime with a higher division of labor. Consequently, by increasing the returns from specialization, improvements in IT make work designs with lower rather than higher degrees of functional flexibility more efficient. In other words, IT and flexible work designs are not complements but substitutes and we therefore expect a negative interaction effect upon productivity.

In contrast, advances in CT are expected to reduce the returns from specialization and increase the returns from multitasking. Lindbeck and Snower (2000) divide the returns from multitasking into two types of task complementarities: technological and informational task complementarities. Technological task complementarities refer to complementarities that arise from the interaction between different types 
of labor inputs (i.e. teamwork). Informational task complementarities refer to complementarities within a given type of labor that arise when the knowledge and information acquired at one task may be used to improve the performance at another task (i.e., job rotation). Advances in modern communication and network technologies accentuated the returns from multitasking by increasing the returns of both types of task complementarities: On the one hand, they promoted technological task complementarities arising in e.g. teamwork by releasing any spatial or temporal barriers to human interaction and better means to group coordination and communication. On the other hand, they increased informational task complementarities that arise through e.g. flexible job-arrangements by providing employees with an efficient access to and an exchange of information through a corporate-wide reach of knowledge and knowledgeable people and permit faster and better decision-making (see Lindbeck \& Snower, 2000; Schienstock et al., 2002).

Advances in CT are thus expected to increase returns from multitasking, which - according to the Boucekkine-Crifo model - induces profit-maximizing firms to transition towards a holistic regime with a lower division of labor and broader task assignments. ${ }^{7}$ As a consequence, by increasing the returns from multitasking, advances in CT makes flexible work designs more efficient and we therefore expect their interaction to yield complementary productivity effects. These observations are also consistent with the results obtained in Dessein and Santos (2006).

\section{Complementarities with workforce training}

The literature on workforce training distinguishes between two discrete ends of a continuum of personnel knowledge formations (cf. Schienstock et al., 2002; Ernst \& Lundvall, 2004; Peansupap \& Walker, 2005): Formal (off-the-job) training are learning activities with a pre- determined content and format and are usually delivered in the traditional class room model. This type of training is particularly suited to transfer explicit and well-codified knowledge ('hard' and technical skills). By contrast,

\footnotetext{
${ }^{7}$ In the Boucekkine-Crifo model, for simplicity only informational task complementarities are active because they were sufficient to make the argument.
} 
informal (on-the-job) training is much less structured and usually occurs directly on the job through learning-by-doing, learning-by-using and learning-by-interacting with technical, social and organizational norms. Informal training thereby emphasizes and promotes the acquisition of tacit knowledge, the type of knowledge, which is hard to communicate but best, acquired through practice and experience ('soft' and social skills). Here, workforce training refers to the intensity of formal training, defined as the fraction of the total workforce participating in formal training activities.

In today’s rapidly changing environments previously acquired skills may turn insufficient or obsolete and therefore call for a speeded up process of learning and a continuous adjustment of skills in order to keep up with the frequent changes (OECD, 2002; Ernst \& Lundvall, 2004; Martinez-Sanchez et al., 2011). Skill upgrading is not only sufficient; it is also necessary for a successful implementation of technological and organizational innovations because these changes largely depend on individuals’ ability to absorb the change, which is typically positively associated with higher levels of human capital and well-functioning training systems (Arnal et al., 2003). Advances in IT and CT are therefore both held to be complementary with training; each, however, may interact distinctively with training.

First, formal learning can either take place in the form of guided learning from domain experts and superiors or in a non-guided form via self-learning (Peansupap \& Walker, 2005). Along the lines of Garicano (2000)'s framework, better ITs enable cheaper information acquisition and thus promote selflearning. Advances in CTs, instead, decrease communication cost, make supervisor consultation more efficient and therefore promotes the guided form of training: 'learning from experts'. In terms of learning performance, these two approaches may however differ. Indeed, the literature on cognitive performance and instructional research for formal training is decisive and finds significant differences between these two forms of learning. Kirschner et al. (2006) posit that "evidence from empirical studies over the past half-century [...] consistently indicate that minimally guided instruction is less effective and less efficient than instructional approaches that place a strong emphasis on guidance of the [...] learning process.” (p. 75). Hence, we consider the guided form of learning, as promoted by CTs, to be superior in terms of performance than a minimally guided form of learning, which is promoted by IT. 
Second, in line with the Boucekkine-Crifo model, a higher division of labor tends to result in simpler jobs and tasks that require a less diverse set of skills and hence require less intensive training (Schienstock et al., 2002). Multi-tasking practices, instead, generally demand a more diverse set of skills and a higher level of human capital, which can be acquired through a sufficient amount of training (Martinez-Sanchez et al., 2011). According to our previous discussion, we expect that CT promotes multitasking more strongly than IT does. Hence, CT should affects the need for training more intensively than IT does.

Finally, a similar perspective is supported from a system complexity point of view. By combining and connecting stand-alone IT applications through network technologies, the system's complexity degree and information content scales disproportionally. In other words, we consider combinatorial network technologies as main drivers behind a system's complexity and if human-mediated interactions with interconnected systems require an understanding of the whole system, we consider training as particularly important in the presence of communication and network technologies.

These arguments lead us to expect that while both IT and CT are complementary with training, the interaction between IT and training is smaller than the interaction between CT and training.

Table 1 summarizes the direction and relative size of all effects that we predict concerning the impact of the combined use of distinct ITs and CTs as well as different types of organizational capital on firm productivity. As the interactions of employee voice and work design with IT and CT are expected to be of opposing signs it follows that the positive effects are larger than the negative effects. The following sections investigate these predictions empirically.

\section{DESCRIPTION OF THE DATA}

Our empirical analysis is based on representative data from the KOF Innovation Survey, which is similar in content and structure to the well-established Community Innovation Survey (CIS) in other European countries. The KOF Innovation Survey, available online in all Swiss national languages (French, Italian and German) at www.kof.ethz.ch/en/surveys/structural-surveys/innovation-survey, contains questions about innovation activities and their intra-firm diffusion, and also collected information on financial 
variables as well as basic structural characteristics of the firms. Unlike the CIS surveys, the KOF Innovation Survey contains an extensive section on the use of ICT technologies (internet, intranet, extranet, etc.), and the use of new organizational practices (job rotation, teamwork, employees’ involvement in decision-making, etc.). The surveys are sent to the executive board of the companies in paper form. Given the broad set of questions, the paper-based form of the survey allows them to hand out individual survey parts to the respective field experts, which further increases the probability of accurate responses.

We make use of four waves of the survey conducted in 2002, 2005, 2008 and 2011, respectively. All four surveys are based on a representative sample covering Switzerland's manufacturing, construction industry and business services and employ a stratification by 29 industries and 3 industryspecific firm size classes that fully cover large firms. The raw data contains information for 2583, 2555, 2172 and 2363 firms, which represents an average response rate of 37 percent. This response rate is satisfactory given the very demanding questionnaire. In all four surveys, selective phone-calls were made among those companies that were underrepresented in the initial round of data collection so as to ensure that the final structure of the dataset is similar to the underlying sample in terms of industry affiliation and firm size. Accordingly, the characteristics of the responding firms should be relatively representative for the whole industry structure. Despite these efforts in increasing representativeness of the sample, a certain selection bias in our regressions due to unit or item non-response to the survey cannot be ruled out, as non-response may be systematically related to certain variables of interest (e.g., the use of ICT). We thus need to be careful in generalizing the estimation results to the universe of Swiss firms. Moreover, as there is a relatively large time lag of three years between the surveys, only about half of the firms replied to two consecutive surveys, causing our panel to be (highly) unbalanced.

By pooling the dataset we have a total of 7090 observations. The final sample used for model estimation was considerably smaller (about 4000 observations) primarily because the survey’s question on organizational practices were only answered by firms with at least 20 employees. When controlling for firm fixed effects, the number of firms further decreases to 2700 observations ("N") and about 1200 
firms ("Groups”) due to the unbalanced nature of the sample; $50 \%$ of them answered two surveys, $40 \%$ three surveys, and 10\% answered all four surveys. On average, the firms in our sample have 412 employees (median: 110 employees), whereupon 45\% have less than 100 employees. 55\% of the firms belong to the manufacturing sector, $36 \%$ to the service sector and $9 \%$ to the construction sector.

To measure ICT we use the employment shares that regularly use computerized devices such as personal computers, workstations, terminals or laptops (computer_user_share) and data intranets (intranet_user_share), respectively. In line with most previous studies in this area (see Draca et al., 2006), our measures thus refer to the use of ICT tools rather than stocks of ICT capital. Besides information on ICT usage, the KOF Innovation Survey also includes information on the firms' ICT investment. But since we have this information only for the years in which the data were collected, we cannot build any proper measures of ICT capital stock.

As discussed previously, the study aims to separate the complementarity effects of different components of a firm's organizational and technological capital. Concerning our technological capital measures we distinguish between IT and CT. A key technological innovation affecting communication is the growth of intranets (see Bloom et al. 2014), which should also be a valid proxy for CT in our observation period of 2002-2011. Previously, such document transmissions from plants to headquarters took place via postal mail or fax, which caused high communication costs and prohibited smooth information flows and fast decision-making. The installation of corporate intranets, instead, integrated an organization's information systems into a single system and enabled employees to find, share and communicate any information needed for their work (Boersma \& Kingma, 2006).

To proxy IT, the literature often refers to the use of technologies for Enterprise-Resource-Planning (ERP), Customer-Relationship-Management (CRM) and Supply-Chain-Management (SCM) (see Banker et al., 2006; Heim \& Peng, 2010; Hendricks et al., 2007). Although the survey includes information on the use of these technologies, we only have information on whether the firms use these technologies or not, but we do not know how intensively they are used. Hence, within-firm variation is limited, which makes it difficult to identify potential complementarities with these measures in our 
setting that controls for firm fixed effects. As a first step, we will thus separate the effect of IT and CT econometrically (see Section 4.3). In a second step, results based on direct measures of IT usage are presented in the robustness section.

Concerning organizational capital we distinguish between the three components employee voice, work design and workforce training (other components of organizational capital are discussed in an extension to the main model). The data includes detailed information on the firms' workforce organization that allows us to construct adequate measures for all three components of organizational capital. Our measure of employee voice primarily refers to autonomy and is based on seven items that measure the extent of competencies with respect to work speed, task sequence, task assignment, task execution, production problems, client contact, and client complains. Work design is proxied by two items that measure the extent of team work and job rotation, respectively. To directly test our predictions, we combine the information on the six and two items referring to employee voice and workforce training, respectively, in two overall measures. In order to deal with potential differences in the relevance of the different items, we combine them by taking the mean of the standardized values (see Bresnahan et al., 2002 for a related procedure). The composition of the different items is largely confirmed by factor analysis (see Table A.9). ${ }^{8}$ Nevertheless, to identify potential differences among the different items, all items are also tested separately in the robustness section (see Table A.6). Finally, the share of employees taking part in continued training is used as measure for workforce training. In addition to information on these three elements of organization capital, the dataset also contains information on firm structure or incentive pay schemes. In order to get a complete picture of the effect of organization capital, the effect of these elements is also tested as an extension to the main model (see Section 5.2). For a more detailed description of these variables and all other model variables see Table 2.

\footnotetext{
${ }^{8}$ Moreover, the factor analysis indicates that the measures of delayering and incentive pay, in fact should be considered separately. The respective results are thus discussed in an extension to the main model (see Section 5.2).
} 


\section{ECONOMETRIC FRAMEWORK}

\subsection{Model specification}

As Hempell (2006) pointed out, the idea of complementarities or synergies was theoretically formalized based on the fairly general mathematical model of supermodularity. The theory has two implications as of how complementarities can be tested on empirical grounds: Either via examining correlations of factor demands or by testing the effect of combinations of ICT usage and organizational practices on firm productivity (see Brynjolfsson \& Milgrom, 2013). A drawback of examining correlations is that even if correlations between practices are well-measured, decision makers may not have sufficient information to choose efficiency or output enhancing combinations of practices. Moreover, unobserved heterogeneity between different practices makes it difficult to correctly identify potential complementarities based on the study of correlations (see Athey and Stern 1998). The latter approach does not have these drawbacks and can serve as a direct test for complementarity or substitutability (see Carree et al. 2011). Similar to prior studies such as Aral and Weill (2007), we thus adopt the latter, more direct approach and estimate the following relation:

$\log \left(y_{i j t}\right)=\beta_{1} k_{i j t}+\beta_{2} o_{i j t}+\beta_{3}\left(k_{i j t} * o_{i j t}\right)+\beta_{4} z_{i j t}+\alpha_{i}+\alpha_{j t}+\epsilon_{i j t}$,

where $y_{i j t}$ is the dependent variable given as the value added per employee of firm $i$, which operates in industry $j$, at time $t, k_{i j t}$ and $o_{i j t}$ denotes the stacked (column-)vectors of technological and organizational variables, respectively, $z_{i j t}$ denotes controls and $\epsilon_{i j t}$ the stochastic error. In order to absorb any firm-specific shocks and industry-specific shocks over time, we include further controls for firm fixed effects $\left(\alpha_{i}\right)$ and industry-specific time fixed effects $\left(\alpha_{j t}\right)$.

To reduce a potential omitted variable bias further, we include measures for the firms’ technological and organizational capital in the baseline model. More specifically, following canonical specifications of simple production functions (see, e.g., Griliches and Mairesse 1998), the estimates include measures of 
production inputs both the quantity and quality of labor inputs (employment_number, tertiary_share), capital inputs (non_ICT_investment) ${ }^{9}$ and R\&D expenditures (r\&d_expenditures). Moreover, we control for whether the company is foreign-owned (foreign_owned), the intensity of price (price_competition) and non-price competition (non_price_competition).

In an extended version of the baseline model we additionally include controls for whether the firm has experienced company restructuring in the form of spinoffs (sale_of_division), outsourcing (outsourcing), takeovers (takeover) or merging (merger), which may directly affect the performance of the firms. To deal with autocorrelation and heteroskedasticity, we present standard errors that are robust to heteroskedasticity and clustered at the firm-level (clustered sandwich estimator). In order to deal with skewed data quantitative measures such as value added per employee or the number of employees are in logs (see Table 2 and Table A.1 for an exact definition of the model variables and descriptive statistics, respectively).

\subsection{Testing for complementarities}

As indicated above, we identify potential complementarities between a firm’s technological and organizational capital by individually interacting the ICT variables with the measures of workplace organization. ${ }^{10}$ Complementarities are present if the marginal productivity depends positively on the level of other productive factors, or in technical terms, once the cross-partial derivative is positive, $\partial^{2} y_{i t} / \partial k_{i t} \partial o_{i t}>0$. To visualize the different interaction effects, we present the average marginal

\footnotetext{
${ }^{9}$ As we have this information only for the years in which the survey was collected, and only very few firms answered all four surveys, it is not possible to construct an adequate capital stock variable. However, by matching further data, we are able to partially limit these concerns in a robustness specification in which we use information on the firm's net investments in the previous four years (instead of just one year) prior to the survey, which improves our measurement of the firm's true capital intensity. Because these data are available only for the subsample of firms that also participated in the quantitative KOF investment surveys, including this better proxy of the capital-output ratio leads to a substantial drop in sample size. As the inclusion of this variable does not affect the estimation results (results are available on request), we thus decided to control in our model specifications for capital input only. However, as capital intensity is to a large extent firm- and/or industryspecific, the effect from the use of capital will to a large extend be captured by the detailed controls for industry affiliation and firm fixed effects.

${ }^{10}$ In contrast to previous studies in this field of research (e.g., Cassiman and Veugelers 2006, Bertscheck and Kaiser 2005), we have continuous measures for both ICT usage and organizational capital. Hence, it does not make sense to construct exclusive combinations of the two. However, to visualize the interaction effects, we will present figures that show the average marginal effects of ICT usage for different levels of organizational capital (see Figure 2).
} 
effects of intranet use and computer use, respectively, for different levels of organizational capital (see Figure 2).

As the measures of technological and organizational capital are likely to be correlated, we obviously face a trade-off when simultaneously including multiple interactions in a single model. On the one hand, this allows us to avoid potential endogeneity concerns due to an omitted variable bias and thus to identify the different complementarity effects more properly. On the other hand, however, we may thereby introduce a multicollinearity problem, as the different variables are highly correlated. ${ }^{11}$ We will deal in Section 5 with this issue in two ways: First, we will assess the robustness of the results by comparing the estimation results that simultaneously include all interactions with those that include the different interaction terms separately (see Table 3 and Table A.5). This allows us to evaluate the severity of a potential omitted variable bias if we do not simultaneously include the different interaction terms. Second, we will fix the organizational variables over time by taking for each firm the mean values of the available observations. As the firm fixed effects will then absorb the linear terms of the organizational variables we do not need to include the linear terms of the organizational variables explicitly and are therefore able to include fewer collinear variables, which may reduce the multicollinearity problem while still allowing us to identify the interaction effects. ${ }^{12}$ Bloom et al. (2012), who also use fixed organizational variables, argue that, at least in the short term, the assumption of quasi-fixed management practices is plausible, because management practices are difficult to change over time at the firm level (see also Tambe et al., 2012 for a similar argument; for a theoretical justification of this argument see Milgrom \& Roberts, 1990 or Bresnahan et al., 1996). In line with this prediction, we observe that most variation of the organizational variable is between firms rather than within firms. ${ }^{13}$ Nevertheless, we will

\footnotetext{
${ }^{11}$ At least for firm level survey data the correlation between the different ICT and organizational variables is quite substantial (see Table A.2).

12 Note that the interaction terms with the ICT variables are still identified, even if the fixed effects absorb the linear terms of the organizational variables.

${ }^{13}$ We observe the following standard deviations: employee_voice (overall: 0.62; between: 0.58; within: 0.31), work_design (overall: 0.77; between: 0.70; within: 0.40), workforce_training (overall: 1.08; between: 1.02; within: 0.52).
} 
test in the robustness section whether allowing the organizational variables to vary over time affects the interpretation of our results (see Table A.4).

\subsection{Separating the effect of communication and information technologies}

As described before we only have information on the propensity but not on the intensity of use of IT, which makes it difficult to identify potential complementarities with these measures in our setting that controls for firm fixed effects. However, we have information on the intensity of use of computerized devices and data intranets, respectively. While the former is a typical measure for ICT as a whole, the latter measures the use of CT. Hence, the interaction between use of computerized devices and organizational variables will indicate whether complementarities between ICT and organizational capital exist in general, but it is unclear whether CT or IT drives this effect. However, when additionally controlling for complementarities between intranet use and organizational capital, we should capture the complementarity effect between CT and organizational capital, wherefore the interaction effects with computer use then should reflect mainly complementarities between IT and organizational capital.

A general concern in the analysis of complementarity in organizations is that complementary variables tend to be adopted together - in our case computers and intranet - which makes it hard to distinguish the effects from computers from those of intranets (Brynjolfsson and Milgrom, 2013). Since we not only have information about the availability of technologies, but also know how intensively computers and intranets are used, correlation between the two variables will be much lower and this

problem is significantly reduced. This is supported by our low within-firm correlation between the two technology variables computer_user_share and intranet_user_share, which amounts to only 0.2673. Hence, there appears to be sufficient independent variation in ICT and CT to separate the two effects (see also respective discussion in the robustness section). 


\subsection{Unobserved heterogeneity}

Although a potential omitted variable bias should be significantly reduced in our framework, because a broad set of observables generally affecting the firms’ productivity is included in the estimation equations besides ICT and organizational variables, it cannot be ruled out completely. Unfortunately, there is so far no "magic bullet" to deal with unobserved heterogeneity that simultaneously affects factor inputs and firm productivity (Bloom et al., 2012, p. 175). This is even truer as we do not focus on one specific complementarity but rather analyze complementarities between all different components of technological and organizational capital simultaneously. To date, the best practice to deal with the problem of unobserved heterogeneity is using a "within-group" estimator. Hence, we include a full set of firm fixed effects in our models that control for unobserved time invariant effects. Furthermore, to capture industry-specific shocks over time, we control for industry-specific time fixed effects (NACE 2digit level).

\section{ESTIMATION RESULTS}

\subsection{Main results}

The main results are presented in Table 3. We present the estimation results of our baseline productivity model with firm- and industry-time-fixed effects. ${ }^{14}$ In column (1) we test complementarities between computer use and the three different measures of organizational practices, indicating whether complementarities between ICT as a whole and organizational capital exists. In column (2) we alternatively include the interactions between intranet use and the three organizational variables that measure potential complementarities between CT and organizational capital. Finally, in column (3) we

\footnotetext{
${ }^{14}$ Alternative estimates with time fixed effects instead of industry-time fixed effects are presented in columns (1) to (3) of Table A.3. There are some differences between the two models. As industry-time fixed effects are more conservative and thus better able to control for any unobserved heterogeneity, we will henceforth primarily focus on the estimation results given in column Table 3. The main conclusions, however, also hold for the other models.

In columns (4) to (6) of Table A.3 we additionally include controls for restructuring of the companies. These controls, however, turn out to be statistically insignificant and their inclusion only marginally affects the other estimation results.
} 
simultaneously include all six interaction terms, which should allow us to disentangle the impact of IT and CT (see Section 4.3).

The results in column (1) indicate that complementarities between ICT as a whole and the three subcategories of organizational capital are rather moderate. When we control for industry-time fixed effects, no significant effects can be identified for the direct effect of ICT and its complementarities with employee voice, workforce training and work design, respectively (some complementarity can be identified for employee voice when not controlling for industry-time fixed effects; see column 1 of Table A.3).

The results in column (2) point towards the existence of more complementarities between CT and organizational capital: significant complementarities can be observed between intranet use and work design and intranet use and workforce training, respectively. However, no complementarities can be found between intranet use and employee voice. The relevance of combined use of CT and organizational practices is emphasized by the fact that the direct effect of intranet use tend to be negative, indicating that the use of CT in absence of organizational practices affects a firm's productivity negatively.

As a firm's use of IT and CT is expected to be correlated, the sole inclusion of CT variables probably measures a mixed effect. Hence, more decisive conclusions can be drawn when we simultaneously control for ICT and CT use, as done in column (3). This model should allow us to interpret the intranet variables as ‘pure’ CT effects while the variable for computer use should then capture the 'pure' effect of IT use (see Section 4.3). We will call this model our 'main model' from now on. By simultaneously including all interaction effects, we indeed observe a clearer pattern and this reveals several interesting results. First, in line with our predictions presented in Table 1, employee voice complements IT use, but has a negative interaction effect with CT use on productivity, which is consistent with the findings in Bloom et al. (2014). Second, with respect to work design, consistent with our theoretical predictions, we find negative interaction effects with IT use and positive interaction effects with CT use. Hence, as expected, a combined use of work design practices and CT stimulates 
productivity, whereas the combined use of work design practices and IT hampers productivity.

Furthermore, the direct effect of intranet use now is clearly negative, which indicates that the use of CT in absence of organizational practices negatively affects a firm’s productivity. Third, concerning workforce training we identify significant complementarities with use of CT, but no complementarities with IT. While we do not have any clear explanation for why the interaction effect of workforce training and IT turns out to be insignificant (and negative), the results indicate a larger relevance of workforce training for the use of CT than for the use of IT, which is again in line with our predictions. ${ }^{15}$

In sum, the empirical findings are thus largely in line with our theoretical predictions presented in Table 1. As the effects of combined use of organizational practices and IT mostly show in the opposite direction than the effects of combined use of organizational practices and CT, it is not surprising that we can only identify weak complementarity effects of organizational capital and ICT in general (column 1). Furthermore, a comparison of the results shows that by solely including the CT variables (column 2), the direct effect of intranet use and the interaction effects with employee voice and workforce training are less significant. Hence, the interaction effects seem to capture part of the IT effect, which is not that surprising given that the use of IT and CT is likely to be correlated.

In Figure 2, we visualize the different interaction effects. Based on the estimation results of column (3) of Table 3, we present the average marginal effects of intranet use and computer use, i.e. the marginal effects of IT and CT evaluated at their means, for different levels of organizational capital. A positive slope of these functions indicates that technological and organizational capital are complementary, a negative slope indicates that technological and organizational capital countervail each other. Moreover, the figures illustrate at which intensity of organizational capital, an increase of technological capital significantly affects productivity, namely where the confidence bounds fall below or exceed the zero line. For most interactions, we observe that the marginal effect of technological capital differs for low levels of organizational capital and high levels of organizational capital. Take for

\footnotetext{
15 The effect of combined use of IT and workforce training is larger than the effect of combined use of CT and workforce training (p-value for Wald test of equality of coefficients based on model 9: 0.11).
} 
example the interaction between work design and intranet use in Figure 2, Panel (d). At high levels of work design, an increase of intranet use significantly positively affects productivity, which is in line with our complementarity hypotheses. However, at low levels of work design, we do not only observe significant lower productivity effects of intranet use, but an increase of intranet use even reduces productivity. This result clearly emphasizes that the use of work design and intranet must go hand in hand, otherwise the costs of technology use may even be larger than its benefits. As Figure 2 shows, very similar results do also hold for other combinations of organizational and technological capital.

\subsection{Test additional organizational measures}

In our analysis of organizational capital, we follow Black and Lynch (2005) who proposed to comprise organizational capital into the three components employee voice, work design and workforce training. However, they acknowledged that these three components are not a complete list of all possible elements of organizational capital. For example, span of control (Bloom \& Van Reenen, 2011) and incentive pay (Ichniowski et al. 2000) turned out to be other important structural dimensions of organizational capital. The complementarity of these components is tested as an extension to the main model and the respective results are presented in Table 4. Delayering is used as measure of span of control. Although delayering and employee voice are two distinct concepts, they tend to move together (see Bloom \& Van Reenen, 2011). Hence, we are not surprised to see that the pattern for delayering is related to the pattern observed for employee voice (Caroli and Van Reenen 2001), i.e. a positive correlation is observed with computer use and a negative correlation with intranet use. However, the respective standard errors turn out to be large and we cannot identify significant effects for this variable, which is likely due to the fact that delayering is a binary variable (measuring whether a firm decreased the number of layers in the five years before the survey).

While individual pay should lead to more competition among workers and is likely to decrease their willingness to contribute to teamwork, group and firm payment schemes are expected to stimulate teamwork to achieve the group’s goals (Arvanitis et al. 2016, Ichniowski et al. 2000). As teamwork is an 
important factor contributing to work design, we would expect the group and firm payment schemes to interact similarly with the different technology types as work design. Indeed, this happens to be the case: Group and firm performance salary seem to be complementary with CT and show (weakly significant) negative interactive effects with IT. Finally, the effects for individual performance salary are much lower than for the two other salary measures that more directly contribute to teamwork. Overall, these analyses show that our main results remain robust to the inclusion of these additional dimensions of organizational capital and also show that they are largely in line with theoretical a priori expectations.

\subsection{Robustness tests}

In order to examine the robustness of our main results we pursued several robustness tests. All tests are based on our main model presented in Column (3) of Table 3 that simultaneously includes the computer use and intranet use variables and controls for industry-time fixed effects.

\section{Allow organizational variables to vary over time}

In order to examine the impact of quasi-fixing the organizational variables, Table A.4 presents the estimation results of the main model when we allow the organizational variables to vary over time. An inspection of the estimation results reveal that the effects of the interaction terms all point in the same direction as before, indicating robustness to changes over time. Furthermore, the significance of the effects is only marginally affected. Only the effect of the combined use of computer use and employee voice is somewhat smaller and therefore losing significance.

\section{Separate inclusion of interaction terms}

In order to test how multicollinearity may affect the estimation results, Table A.5 presents the results of the main model with individual inclusion of the different interaction terms. In general the results appear to be reasonably robust. All single coefficients of the interaction terms point in the same direction as before. As we measure a mixed effect of IT and CT without simultaneously controlling for both 
components of ICT, it comes only at little surprise that some of the effects are somewhat smaller and less significant than in the main model (column 3 of Table 3). In general they differ, however, only marginally from the results that we obtained when either testing complementarities with ICT in general (column 1 of Table 3) or CT (column 2 of Table 3).

\section{Test subcategories of overall organizational variables}

To measure work design and employee voice we combined the information of multiple variables (see Section 3). To get an idea about whether the used weighted mean variable really makes sense, we test in Table A.6 whether the effects differ among the respective subcategories. In Columns (1) and (2) we replace the work design variable with its two subcategories. For both variables we find the expected positive interaction effect with intranet use and the negative interaction effect with computer use, even though the negative effect is not statistically significant for job rotation.

Columns (3) to (9) present the estimation results in case we replace the employee voice variable by its subcategories. In general, we observe the expected pattern: a positive interaction effect between computer use and the different types of employee voice, and a negative interaction effect between intranet use and the different types of employee voice. The fact that the pattern is more pronounced for the three variables referring to decisions with respect to work speed, task sequences, and task execution was to be expected, as these variables are generally known to capture important aspects of decentralization (Bresnahan et al., 2002).

In sum, we thus conclude that the observed pattern for the different subcategories is largely in line with the observed pattern for the overall organizational variables. Hence, the composition of the variables does not seem to drive the estimation results. Quite the contrary, the results show that the composition of different variables is important in order to properly identify the different interaction effects. When using the information of the different subcategories of the organizational variables separately, the interaction effects tend to show less explanatory power, which directly affects the significance and size of the direct effects of computer and intranet use, respectively. 


\section{Test direct measures of IT usage}

As we lack information on the intensity of IT usage, we decided to identify the IT effects in a first step econometrically. The estimation results indicate that we are indeed able to properly identify the effects of differential types of technologies: First, although one may expect IT and CT to feature a strong comovement and consequently potentially inflated variances due to collinear technology variables, most of the interaction effects turn out to be statistically significant when we simultaneously incorporate the technology variables (ICT and CT). This indicates that there is sufficient independent variation to separate the effects from IT and CT despite (potential) multicollinearity concerns. Second, the direction of most interaction effects is in line with our expectations for the different organizational variables and previous findings for autonomy (see Bloom et al., 2014). Moreover, the directions of change in the effects when filtering out the effect of CT within the ICT variable to measure the impact of IT, is largely in line with a priori expectations: Due to the countervailing effect of IT and CT only moderate interaction effects are observed for ICT in general, but once we additionally control for interactions with CT, the interaction effects with ICT become statistically significant and also have the expected sign.

To further test the robustness of our results, we present in Table A.7 estimation results that are based on direct measures of IT usage. Concretely, we use information on whether the firms use EnterpriseResource-Planning (ERP), Customer-Relationship-Management (CRM) and Supply-Chain-Management (SCM), which are typical ITs (Banker et al., 2006; Heim \& Peng, 2010; Hendricks et al., 2007).

However, as discussed before, all of them are binary variables that measure whether the firms use these technologies or not. Hence, within-firm variation is limited. ${ }^{16}$ It is thus not surprising that the standard errors of these variables are quite large in our setting that controls for firm fixed effects, which aggravates the identification of potential complementarities. Nevertheless, the direction of the effects is largely in line with the findings of our main model: While employee voice is positively related to IT,

\footnotetext{
${ }^{16}$ We observe the following standard deviations: ERP (overall: 0.49; between: 0.46; within: 0.21), CRM (overall: 0.48; between: 0.44; within: 0.23), SCM (overall: 0.35; between: 0.31; within: 0.18 ).
} 
work design shows a negative correlation. The pattern is less clear for workforce training. Depending on the chosen measure for IT, positive or negative interaction effects with workforce training are found. However, in line with our main results, all these interaction effects with workforce training are relatively small in size and clearly insignificant.

\section{Test differences over time}

The period considered in the main model is quite long (2002-2011). As ICT evolved quite rapidly over this period, the findings of our main model may be driven by a specific period in time. To further test the robustness of our results, we estimate our main model for alternative time windows (see Table A.8). The estimation results largely confirm our previous findings. Columns (1) to (3) indicate that the complementarity between ICT and employee voice decreases over time, while the complementarity with workforce training increases. The results in Column (4), however, show that these differences seem to be primarily driven by the shorter time period rather than potential changes in the effects over time.

\section{CONCLUSIONS}

A promising avenue in the empirical and theoretical literature on digitization and firm productivity has put forth the complementarity hypothesis between technological and organizational capital. However, the literature so far, adopted primarily an aggregate perspective by using broad conceptual measures and composite indicators for either one or both, technological and organizational capital. We argue that such an aggregate and non-differentiated perspective falls short of the mark and leaves the complementary nature incompletely understood. This article puts forth a conceptual framework based on a comprehensive taxonomy of technology and organization and adopts a differentiated perspective to pursue a more nuanced analysis of the existent complementarities among the different components of technological and organizational capital (see Table 1 for a summary of predictions). This matters to business executives because it allows them to better understand how digital technologies are most effectively implemented to promote productivity (Dedrick et al., 2003) and it matters to policy makers to 
foster policy landscapes that embrace the power of ICT and seize the digital opportunity (Brynjolfsson \& Saunders, 2010; Crespi et al., 2007).

Based on recent contributions in the literature, the conceptual framework employed in this article argues that IT and CT exert distinct and often opposed forces on the optimal degree of decision authority, functional flexibility and training intensity. First, we argue that the optimal degree of decision authority at any given level of hierarchy is driven by the trade-off between information acquisition and communication costs. IT should promote higher levels of decentralized decision power by lowering information acquisition costs and is therefore expected to interact positively with employee voice. CT, instead, should unleash tendencies towards centralized decision-making by decreasing communication costs, which interferes with higher levels of employee voice and is therefore conjectured to entail negative interactive productivity effects. Second, organizations may either rely on low functional flexibility to reap the returns from task specialization and intra-task learning due to scale economies or they may emphasize broad task assignments to reap the benefits from task complementarities and intertask learning due to scope economies. While advances in IT should increase returns to specialization, IT is considered to promote not more but less flexible work designs and is therefore expected to feature a negative interaction effect upon productivity. Improvements in CT, instead, should increase the returns from multitasking and interact in a mutually reinforcing way with higher degrees of functional flexibility giving rise to superadditive productivity effects. Third, while we expect workforce training to be complementary with both IT and CT, because rapid technological and organizational progress require a constant upgrading of skills, we expect CT to unleash stronger impacts for the need of training than IT because - to name one reason among others - networking technologies are the main driver for system complexity.

We confirm most of these predictions using a comprehensive panel dataset from four consecutive waves of the KOF Innovation Survey, which is similar in content and structure to the well-established Community Innovation Survey (CIS) in many European countries, and covers a representative sample of the Swiss firms over the post millennium years (from 2002 to 2011). In terms of identification, we 
employ a 'best-practice' within-group estimation and include both a full set of firm fixed effects to control for unobserved time invariant effects and industry-specific time fixed effects to capture any industry-specific shocks. Moreover, our results appear to be robust with respect to the assumption of time-invariant organizational variables, separate inclusion of interaction terms and the construction of our organizational variables.

The study thereby confirms that the distinction between IT and CT is important, which has implications for research. Although some evidence of complementarity between ICT and organizational capital has been found in previous studies (see Brynjolfsson et al., 2002; Bresnahan et al., 2002; Crespi et al., 2007), our results indicate that the effects for most components of organizational capital go in opposite directions. Hence, the effect of ICT seems to decrease when mixing up information and communication technologies, and may - as in our case - even become insignificant. This may partly explain the inability of quite many studies to assess any notable complementarities between technological and organizational capital based on overall ICT measures (see Bertscheck \& Kaiser, 2001; Caroli \& Van Reenen, 2001; Black \& Lynch, 2004; Arvanitis \& Loukis, 2009). Moreover, the results indicate that evidence by Bloom et al. (2014) for authority and a wider span of control cannot be extended to organizational capital in general, and thereby confirms our predictions that the distinction between different components of organizational capital is important to properly identify complementarity effects with ICT.

With regards to management implications, our results clearly indicate that firms have to harmonize their ICT infrastructure and organizational practices. They suggest on the one hand that firms who wish to efficiently endow their workers with a higher degree of employee voice should prioritize their infrastructure investments in IT over those in CT. On the other hand, firms who aim to fully embrace flexible work designs and intensive workforce training, instead, should primarily fuel investments in CT rather than IT. Moreover, as the effects of different components of organizational capital go in opposite directions, the results also indicate that extensive use of multiple components of organizational and technological capital may not maximize firm productivity. 
There are several directions from this line of research: First, from a theoretical point of view, the true wait is for a theory that is able to explain these empirical phenomena within a unified theoretical framework. Second, more often than not, firms rather employ hybrid than single forms of the organizational modes considered, e.g. a mixture of low and high functional flexibility or a combination decentralization and centralization among different establishments, hierarchical levels or skill groups. As we expect the results to be even more clear-cut at more granular levels, it may be empirically sensible to examine the proposed framework at an establishment or even worker level. Moreover, studies based on qualitative and case-based analyses à la Bartel, Ichniowsky, Shaw and co-authors provide a close and careful look at the key mechanisms and are expected to reveal important insights (see Ichniowsky and Shaw (2013) for a review). Third, it will be interesting to see whether our findings also hold for new types of communication and information technologies. If we may cast a glance into the future about on-going technological developments, the analysis put forth in this article suggests that managers who aim to increasingly employ innovations in the realm of information technologies, most notably artificial intelligence and machine learning, may avail themselves of the complementary nature with organizational practices by empowering employees with more decision authority because these innovations will most likely significantly reduce the costs associated with the acquisition and the processing of information. Moreover, to the extent that we may understand the recent surge of the Internet of Things as advances in communication and network technologies, our framework suggest that organizations who wish to make intensive use thereof should enable functionally flexible work organizations and foster their workforce training programs to reap the complementary productivity effects. The growing availability of data in these domains holds the promise of exciting future research.

\section{REFERENCES}

Aral, S., \& Weill, P. (2007). IT assets, organizational capabilities, and firm performance: How resource allocations and organizational differences explain performance variation. Organization Science, 18(5), 763-780.

Arnal, E., Ok, W., \& Torres, R. (2003). Knowledge, work organisation and economic growth. Springer. 
Arvanitis, S. (2005). Modes of labor flexibility at firm level: Are there any implications for performance and innovation? Evidence for the Swiss economy. Industrial and Corporate Change, 14(6), 9931016.

Arvanitis, S., \& Loukis, E. N. (2009). Information and communication technologies, human capital, workplace organization and labour productivity: A comparative study based on firm-level data for Greece and Switzerland. Information Economics and Policy, 21(1), 43-61.

Arvanitis, S., Seliger, F., \& Stucki, T. (2016). The relative importance of human resource management practices for innovation. Economics of Innovation and New Technology, 1-32.

Athey, S., \& Stern, S. (1998). An empirical framework for testing theories about complimentarity in organizational design (No. w6600). National Bureau of Economic Research.

Atkinson, J. (1984). Manpower Strategies for Flexible Organisations. Personnel Management, 16(8), 28-31.

Autor, D. H., Levy, F., \& Murnane, R. J. (2002). Upstairs, downstairs: Computers and skills on two floors of a large bank. ILR Review, 55(3), 432-447.

Autor, D. H., Levy, F., \& Murnane, R. J. (2003). The skill content of recent technological change: An empirical exploration, Quarterly Journal of Economics, 118(4), 1279-1333.

Autor, D. H. (2012). Market Structure, Organizational Structure and Wage Structure. Massachusetts Institute of Technology (MIT), Lecture Note 3 (course: 14.662), 1-22

Banker, R. D., Bardhan, I. R., Chang, H., \& Lin, S. (2006). Plant information systems, manufacturing capabilities, and plant performance. MIS quarterly, 315-337.

Becker, G. S., \& Murphy, K. M. (1992). The division of labor, coordination costs, and knowledge. The Quarterly Journal of Economics, 107(4), 1137-1160.

Bertschek, I., \& Kaiser, U. (2004). Productivity Effects of Organizational Change: Microeconometric Evidence. Management Science, 50(3), 394-404.

Biagi, F. (2013). ICT and Productivity: A Review of the Literature (Tech. Rep.). Institute of Prospective Technological Studies, Joint Research Centre.

Black, S. E., \& Lynch, L. M. (2004). What's driving the new economy? The benefits of workplace innovation. The Economic Journal, 114(493), F97-F116.

Black, S. E., \& Lynch, L. M. (2005). Measuring Organizational Capital in the New Economy. In Measuring Capital in the New Economy (pp. 205-236). University of Chicago Press.

Bloom, N., Garicano, L., Sadun, R., \& Van Reenen, J. (2014). The Distinct Effects of Information Technology and Communication Technology on Firm Organization. Management Science, 60(12), 2859-2885.

Bloom, N., \& Van Reenen, J. (2011). Human resource management and productivity. Handbook of Labor Economics, 4, 1697-1767.

Bloom, N., Sadun, R., \& Van Reenen, J. (2012). Americans do it better: Us multinationals and the productivity miracle. The American Economic Review, 102(1), 167-201.

Boersma, K., \& Kingma, S. (2006). Intranet and organizational learning. Encyclopedia of Knowledge Management, 305.

Bolton, P., \& Dewatripont, M. (1994). The firm as a communication network. The Quarterly Journal of Economics, 809-839.

Bolton, P., \& Dewatripont, M. (2013). Authority in organizations. Handbook of Organizational Economics, 342-372.

Boucekkine, R., \& Crifo, P. (2008). Human capital accumulation and the transition from specialization to multitasking. Macroeconomic Dynamics, 12(03), 320-344.

Bresnahan, T. F., Brynjolfsson, E., \& Hitt, L. M. (2002). Information technology, work- place organization, and the demand for skilled labor: Firm-level evidence. Quarterly Journal of Economics, 339-376. 
Bresnahan, T.F., \& Greenstein, S. (1996). Technological progress and co-invention in computing and in the uses of computers, Brookings Papers on Economic Activity, 1-78.

Brynjolfsson, E., Hitt, L. M., \& Yang, S. (2002). Intangible assets: Computers and organizational capital. Brookings papers on economic activity, 2002(1), 137-181.

Brynjolfsson, E., \& McAfee, A. (2014). The second machine age: Work, progress, and prosperity in a time of brilliant technologies. WW Norton \& Company.

Brynjolfsson, E., \& Milgrom, P. (2013). Complementarity in Organizations. In R. Gibbons \& J. Roberts (Eds.), The Handbook of Organizational Economics (p. 11-55). Princeton University Press.

Brynjolfsson, E., \& Saunders, A. (2010). Wired for Innovation: How Information Technology Is Reshaping the Economy, MIT Press.

Caroli, E., \& Van Reenen, J. (2001). Skill-biased organizational change? Evidence from a panel of british and french establishments. Quarterly Journal of Economics, 1449-1492.

Carree, M., Lokshin, B., \& Belderbos, R. (2011). A note on testing for complementarity and substitutability in the case of multiple practices. Journal of productivity analysis, 35(3), 263-269.

Chwelos, P., Ramirez, R., Kraemer, K. L., \& Melville, N. P. (2010). Research Note-Does Technological Progress Alter the Nature of Information Technology as a Production Input? New Evidence and New Results. Information Systems Research, 21(2), 392-408.

Crespi, G., Criscuolo, C., \& Haskel, J. (2007). Information Technology, Organisational Change and Productivity: Evidence from UK Firms. Centre for Economic Policy Research Discussion Paper 6105.

Dankbaar, B. (1997). Lean production: denial, confirmation or extension of sociotechnical systems design?. Human relations, 50(5), 567-583.

Dedrick, J., Gurbaxani, V., \& Kraemer, K. L. (2003, March). Information technology and economic performance: A critical review of the empirical evidence. ACM Computing Surveys, 35(1), 1-28.

Dessein, W., \& Santos, T. (2006). Adaptive organizations. Journal of Political Economy, 114(5), 956995.

Draca, M., Sadun, R., \& Van Reenen, J. (2006). Productivity and ICT: A review of the evidence (Tech. Rep.). Centre for Economic Performance, LSE.

Ernst, D., \& Lundvall, B.- ${ }^{\circ}$ A. (2004). Information Technology in the Learning Economy: Challenges for Developing Countries. In E. Elgar (Ed.), Globalization, Economic Development and Inequality An Alternative Perspective (pp. 258-287). Edward Elgar Publishing.

Garicano, L. (2000). Hierarchies and the Organization of Knowledge in Production. Journal of Political Economy, 108(5), 874-904.

Garicano, L., \& Rossi-Hansberg, E. (2006). Organization and Inequality in a Knowledge Economy. Quarterly Journal of Economics, 121(4).

Garicano, L., \& Rossi-Hansberg, E. (2015). Knowledge-Based Hierarchies: Using Organizations to Understand the Economy. Annual Review of Economics, 7, 1-30.

Garicano, L., \& Wu, Y. (2012). Knowledge, communication, and organizational capabilities. Organization Science, 23(5), 1382-1397.

Griliches, Z., \& Mairesse, J. (1998). Production Functions: The Search for Identification. In Econometrics and Economic Theory in the 20th Century: The Ragnar Frisch Centennial Symposium (p. 169).

Gurbaxani, V., \& Whang, S. (1991). The impact of information systems on organizations and markets. Communications of the ACM, 34 (1), 59-73.

Heim, G. R., \& Peng, D. X. (2010). The impact of information technology use on plant structure, practices, and performance: an exploratory study. Journal of Operations Management, 28(2), 144-162. 
Hempell, T. (2006). Computers and Productivity: How Firms Make a General Purpose Technology Work (Vol. 33). Springer Science \& Business Media.

Hendricks, K. B., Singhal, V. R., \& Stratman, J. K. (2007). The impact of enterprise systems on corporate performance: A study of ERP, SCM, and CRM system implementations. Journal of operations management, 25(1), 65-82.

Hitt, L. M., \& Brynjolfsson, E. (1997). Information Technology and Internal Firm Organization: An Exploratory Analysis. Journal of Management Information Systems, 81-101.

Huang, I., Guo, R., Xie, H., \& Wu, Z. (2012). The convergence of information and communication technologies gains momentum. The Global Information Technology Report, 35-45.

Ichniowski, C., Kochan, T.A., Levine, D.I., Olson, C., Strauss, G., 2000. What works at work: overview and assessment. In: Ichniowski, C., Levine, D.I., Olson, C., Strauss, G. (Eds.), The American Workplace. Skills Compensation and Employee Involvement. Cambridge University Press, Cambridge, pp. 1-37.

Kirschner, P. A., Sweller, J., \& Clark, R. E. (2006). Why minimal guidance during instruction does not work: An analysis of the failure of constructivist, discovery, problem-based, experiential, and inquiry-based teaching. Educational psychologist, 41(2), 75-86.

Lazear, E. P., \& Gibbs, M. (2008). Personnel Economics in Practice. John Wiley \& Sons.

Lindbeck, A., \& Snower, D. J. (2000). Multitask learning and the reorganization of work: from tayloristic to holistic organization. Journal of Labor Economics, 18(3), 353-376.

Loveman, G. W. (1994). An Assessment of the Productivity Impact of Information Technologies. In T. J. Allen \& M. S. S. Morton (Eds.), Information Technology and the Corporation of the 1990s: Research Studies (pp. 84-110). Oxford University Press New York, NY.

Lundvall, B.-A. (2004). Why the New Economy is a Learning Economy (Tech. Rep.). DRUID, Copenhagen Business School, Department of Industrial Economics and Strategy/Aalborg University, Department of Business Studies.

Malone, T. W. (1997). Is empowerment just a fad? Control, decision making, and IT. MIT Sloan Management Review, 38(2), 23.

Martınez-Sanchez, A., Vela-Jiménez, M.-J., Pérez-Pérez, M., \& de Luis-Carnicer, P. (2011). The dynamics of labour flexibility: Relationships between employment type and innovativeness. Journal of Management Studies, 48(4), 715-736.

McElheran, K. (2014). Delegation in multi-establishment firms: Evidence from it purchasing. Journal of Economics \& Management Strategy, 23(2), 225-258.

Milgrom, P., \& Roberts, J. (1990). The Economics of Modern Manufacturing: Technology, Strategy, and Organization. The American Economic Review, 511-528.

Milgrom, P., \& Roberts, J. (1995). Complementarities and fit: Strategy, structure, and organizational change in manufacturing. Journal of Accounting and Economics, 19(2), 179-208.

Nevo, S., \& Wade, M. R. (2010). The formation and value of IT-enabled resources: antecedents and consequences of synergistic relationships. MIS Quarterly, 163-183.

OECD (2002). Education at a Glance: OECD Indicators 2002. Organization for Economic Co-Operation and Development (OECD).

Osterman, P. (1994). How common is workplace transformation and who adopts it?. ILR Review, 47(2), 173-188.

Peansupap, V., \& Walker, D. H. (2005). Factors enabling information and communication technology diffusion and actual implementation in construction organisations. Electronic Journal of Information Technology in Construction, 10(14), 193-218.

Schienstock, G., Bechmann, G., \& Frederichs, G. (2002). Information society, work and the generation of new forms of social exclusion. SOWING: First Interim Report (Literature Review), 30, 1-139. 
Snower, Dennis J., and Dennis Goerlich. Multitasking and Wages. No. 7426. IZA Discussion Paper, 2013.

Solow, R. M. (1987). We'd better watch out. New York Times Book Review, 36.

Strassmann, P. A. (1990). The Business Value of Computers: An Executive’s Guide. New Canaan, CT, USA: Information Economics Press.

Tiwana, A. (2015). Platform Desertion by App Developers. Journal of Management Information Systems, 32(4), 40-77.

Van Reenen, J., Bloom, N., Draca, M., Kretschmer, T., Sadun, R., Overman, H., \& Schankerman, M. (2010). The Economic Impact of ICT. Final report.

Van Zandt, T. (1999). Real-time decentralized information processing as a model of organizations with boundedly rational agents. The Review of Economic Studies, 66(3), 633-658.

Voudouris, I. (2007). The Co-Evolution of Functional and Numerical Flexibility: Do Technology and Networking Matter? New Technology, Work and Employment, 22(3), 224-245.

Walker, P. (2015). Contracts, entrepreneurs, market creation and judgement: the contemporary mainstream theory of the firm in perspective. Journal of Economic Surveys, 29(2), 317-338.

Whisler, T. L., \& Leavitt, H. J. (1958). Management in the 1980's. Harvard Business Review, 36(6), 4148.

Zand, F., Van Beers, C., \& Van Leeuwen, G. (2011). Information technology, organizational change and firm productivity: A panel study of complementarity effects and clustering patterns in manufacturing and services (Tech. Rep.). University Library of Munich, Germany. 


\section{TABLES}

Table 1: Summary of main theoretical predictions and empirical findings

\begin{tabular}{|c|c|c|c|c|}
\hline & & \multicolumn{3}{|c|}{ Technological Capital } \\
\hline & & Information Technology & & Communication Technology \\
\hline \multirow{9}{*}{ 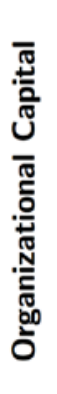 } & Employee Voice & & & \\
\hline & Theoretical prediction & + & $>$ & - \\
\hline & Empirical finding & + & $>$ & - \\
\hline & Work Design & & & \\
\hline & Theoretical prediction & - & $<$ & + \\
\hline & Empirical finding & - & $<$ & + \\
\hline & Workforce Training & & & \\
\hline & Theoretical prediction & + & $<$ & + \\
\hline & Empirical finding & $(-)$ & $<$ & + \\
\hline
\end{tabular}

The ' + ' sign indicates a positive interactive productivity effect due to mutually supportive and reinforcing components. The '-' sign indicates a negative interactive productivity effect due to mutually interfering and competing components. Statistically insignificant empirical findings are presented in brackets ' $(\cdot)$ '. 


\section{Technological and Organizational Capital}

\section{Table 2: Variable definition and measurement}

\begin{tabular}{|c|c|}
\hline Dependent variables & \\
\hline value_added_per_employee & Value added per employee, logarithm \\
\hline Independent variables & \\
\hline computer_user_share & $\begin{array}{l}\text { Employment share that regularly uses computerized devices } \\
\text { (transformation of } 6 \text {-level ordinal variable (level 1: '0\%'; level } 2 \text { : '1-20\%'; level 3: '21-40\%'; level 4: ' } 41-60 \% \text { '; } \\
\text { level 5: '61-80\%'; level 6: ' } 81-100 \% \text { ') to point measures by taking the average between the two ends of } \\
\text { the respective intervals) }\end{array}$ \\
\hline intranet_user_share & $\begin{array}{l}\text { Employment share that regularly uses data intranets } \\
\text { (transformation of } 6 \text {-level ordinal variable (level 1: '0\%'; level 2: '1-20\%'; level 3: '21-40\%'; level 4: ' } 41-60 \% \text { '; } \\
\text { level } 5: \text { ' } 61-80 \% \text { '; level } 6: \text { ' } 81-100 \% \text { ') to point measures by taking the average between the two ends of } \\
\text { the respective intervals) }\end{array}$ \\
\hline IT_intensity & $\begin{array}{l}\text { Number of different IT software used by the firm } \\
\text { (the following software is considered: Enterprise-Resource-Planning (ERP), Customer-Relationship- } \\
\text { Management (CRM) and Supply-Chain-Management (SCM)) }\end{array}$ \\
\hline employee voice & $\begin{array}{l}\text { Extent of decentralization of competencies } \\
\text { (mean of standardized values (mean 0; standard deviation 1) of seven five-level ordinal variables ranging } \\
\text { from 'line manager decides alone' up to 'employee decides alone': 1) speed of work, 2) sequence of tasks, } \\
\text { 3) assignment of tasks, 4) modality of the execution of tasks, 5) problems in production, 6) regular contact } \\
\text { with clients, 7) complaints of clients) }\end{array}$ \\
\hline workforce_training & Share of employees taking part in continued training, logarithm \\
\hline work_design & $\begin{array}{l}\text { Extent of teamwork and job rotation } \\
\text { (mean of standardized values of two six-level ordinal variables ranging from 'very high' (value 5) to 'does } \\
\text { not exist' (value 0)) }\end{array}$ \\
\hline delayering & Decrease in the number of layers in the firm in the five years before the survey yes/no \\
\hline individual_performance_salary & $\begin{array}{l}\text { Extent of compensation based on individual performance } \\
\text { (5-level ordinal variable (level 1: 'low importance'; level 5: 'high importance')) }\end{array}$ \\
\hline group_performance_salary & $\begin{array}{l}\text { Extent of compensation based on workgroup performance } \\
\text { (5-level ordinal variable (level 1: 'low importance'; level 5: 'high importance')) }\end{array}$ \\
\hline firm_performance_salary & $\begin{array}{l}\text { Extent of compensation based on firm performance } \\
\text { (5-level ordinal variable (level 1: 'low importance'; level 5: 'high importance')) }\end{array}$ \\
\hline employment_number & Number of employees (in full-time equivalents), logarithm \\
\hline tertiary_share & Employment share of employees with tertiary-level education, logarithm \\
\hline r\&d_expenditures & R\&D expenditures per employee, logarithm \\
\hline non_ICT_investment & Gross investment expenditure in non-ICT capital per employee, logarithm \\
\hline foreign_owned & Foreign-owned firm yes/no \\
\hline price_competition & $\begin{array}{l}\text { Intensity of price competition } \\
\text { (5-level ordinal variable (level 1: 'very weak'; level 5: 'very strong')) }\end{array}$ \\
\hline non_price_competition & $\begin{array}{l}\text { Intensity of non-price competition } \\
\text { (5-level ordinal variable (level 1: 'very weak'; level 5: 'very strong')) }\end{array}$ \\
\hline outsourcing & $\begin{array}{l}\text { At least one of the following functions has been outsourced in the five years before the survey yes/no: a) } \\
\text { final production, b) intermediate production, c) } R \& D, d) I T, \text { e) other activities. }\end{array}$ \\
\hline takeover & Firms or division of other firms have been taken over in the five years before the survey yes/no \\
\hline merger & Mergers have occurred in the five years before the survey yes/no \\
\hline sale_of_division & Divisions have been sold in the five years before the survey yes/no \\
\hline
\end{tabular}


Table 3: Main results

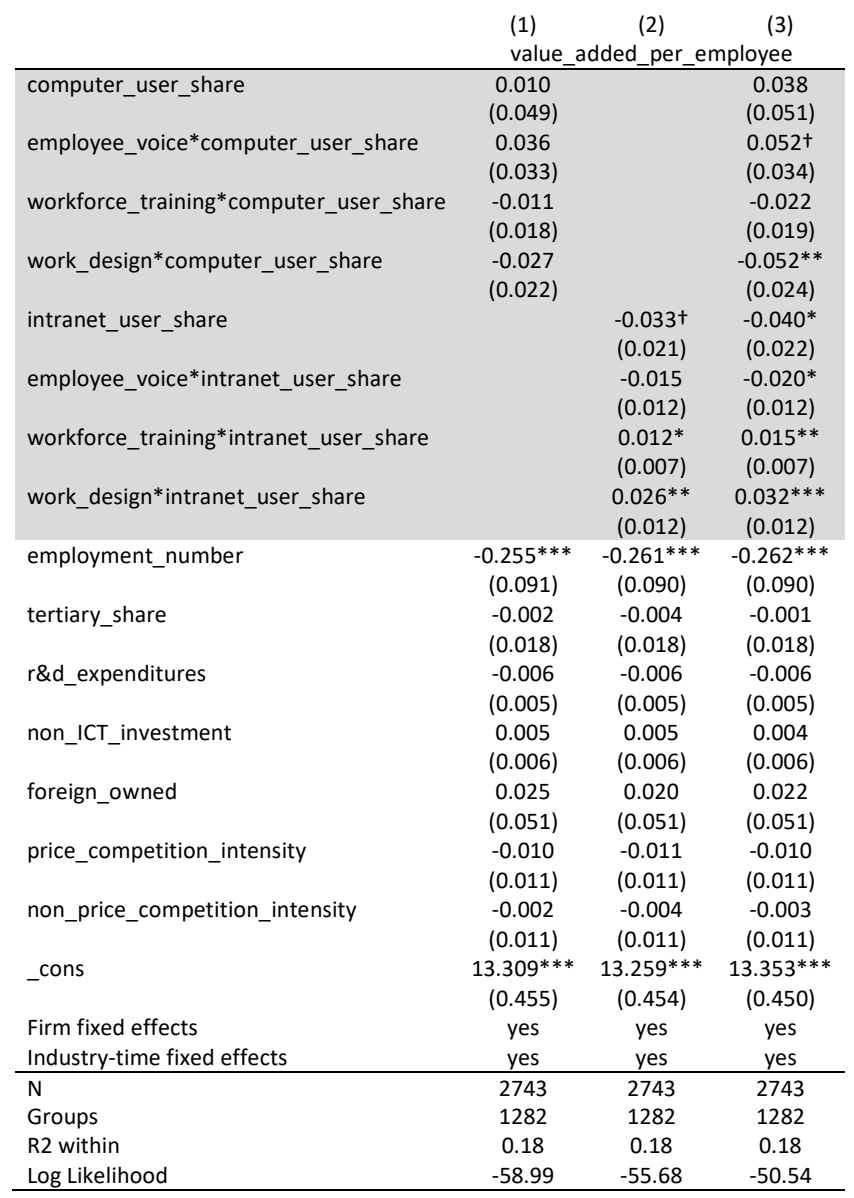

Notes: see Table 2 for the variable definitions; standard errors that are robust to heteroskedasticity and clustered at the firm level (clustered sandwich estimator) are in brackets under the coefficients; $* * *, * *, *,+$ denote statistical significance at the $1 \%, 5 \%, 10 \%$ and $15 \%$ test level, respectively. As we fixed the organizational variables over time (see Section 4.2), we cannot identify the direct effect of organizational capital in our framework that controls for firm fixed effects. 
Table 4: Test the effect of delayering and performance salary

\begin{tabular}{|c|c|c|c|c|}
\hline & (1) & (2) & (3) & \multirow{2}{*}{ ee } \\
\hline & \multicolumn{3}{|c|}{ value_added_per_employee } & \\
\hline \multirow[t]{2}{*}{ computer_user_share } & 0.014 & 0.188 & $0.236^{*}$ & $0.241^{*}$ \\
\hline & (0.059) & $(0.201)$ & (0.125) & $(0.125)$ \\
\hline \multirow[t]{2}{*}{ employee_voice ${ }^{*}$ computer_user_share } & 0.035 & $0.058+$ & $0.064^{*}$ & $0.059+$ \\
\hline & $(0.036)$ & $(0.036)$ & (0.037) & $(0.039)$ \\
\hline \multirow[t]{2}{*}{ workforce_training*computer_user_share } & -0.017 & $-0.036^{*}$ & $-0.040 *$ & $-0.029+$ \\
\hline & $(0.021)$ & $(0.020)$ & $(0.022)$ & $(0.020)$ \\
\hline \multirow[t]{2}{*}{ work_design*computer_user_share } & $-0.064 * * *$ & $-0.055^{* *}$ & -0.034 & $-0.042+$ \\
\hline & $(0.025)$ & $(0.027)$ & $(0.032)$ & $(0.028)$ \\
\hline \multirow[t]{2}{*}{ intranet_user_share } & $-0.036+$ & -0.055 & $-0.078^{* *}$ & $-0.111^{* *}$ \\
\hline & $(0.023)$ & (0.058) & $(0.039)$ & $(0.043)$ \\
\hline \multirow[t]{2}{*}{ employee_voice*intranet_user_share } & $-0.017+$ & -0.018 & -0.019 & $-0.021+$ \\
\hline & $(0.012)$ & (0.014) & (0.014) & $(0.014)$ \\
\hline \multirow[t]{2}{*}{ workforce_training*intranet_user_share } & $0.014^{*}$ & $0.021^{* * *}$ & $0.021^{* * *}$ & $0.021^{* * *}$ \\
\hline & $(0.007)$ & $(0.008)$ & $(0.008)$ & $(0.008)$ \\
\hline \multirow[t]{2}{*}{ work_design*intranet_user_share } & $0.032^{* *}$ & $0.033^{* *}$ & $0.029 *$ & $0.029 * *$ \\
\hline & $(0.013)$ & $(0.016)$ & (0.016) & $(0.015)$ \\
\hline \multirow{2}{*}{ delayering*computer_user_share } & 0.070 & & & \\
\hline & (0.133) & & & \\
\hline \multirow{2}{*}{ delayering*intranet_user_share } & -0.032 & & & \\
\hline & (0.033) & & & \\
\hline \multirow[t]{2}{*}{ individual_performance_salary*computer_user_share } & & -0.027 & & \\
\hline & & $(0.045)$ & & \\
\hline \multirow[t]{2}{*}{ individual_performance_salary*intranet_user_share } & & 0.000 & & \\
\hline & & $(0.013)$ & & \\
\hline \multirow[t]{2}{*}{ group_performance_salary*computer_user_share } & & & $-0.054+$ & \\
\hline & & & $(0.033)$ & \\
\hline \multirow[t]{2}{*}{ group_performance_salary*intranet_user_share } & & & 0.009 & \\
\hline & & & $(0.011)$ & \\
\hline \multirow[t]{2}{*}{ firm_performance_salary*computer_user_share } & & & & $-0.055^{*}$ \\
\hline & & & & $(0.033)$ \\
\hline \multirow[t]{2}{*}{ firm_performance_salary*intranet_user_share } & & & & $0.017+$ \\
\hline & & & & $(0.010)$ \\
\hline \multirow[t]{2}{*}{ _cons } & $13.070 * * *$ & $13.338 * * *$ & $13.335 * * *$ & $13.358 * * *$ \\
\hline & $(0.403)$ & $(0.512)$ & $(0.508)$ & $(0.511)$ \\
\hline Control variables & yes & yes & yes & yes \\
\hline Firm fixed effects & yes & yes & yes & yes \\
\hline Industry-time fixed effects & yes & yes & yes & yes \\
\hline $\mathrm{N}$ & 2672 & 2528 & 2528 & 2528 \\
\hline Groups & 1271 & 1271 & 1271 & 1271 \\
\hline R2 within & 0.18 & 0.17 & 0.18 & 0.18 \\
\hline Log Likelihood & -19.89 & -41.07 & -37.83 & -37.37 \\
\hline
\end{tabular}

Notes: see Table 2 for the variable definitions; standard errors that are robust to heteroskedasticity and clustered at the firm level (clustered sandwich estimator) are in brackets under the coefficients; $* * *, * *, *,+$ denote statistical significance at the $1 \%, 5 \%, 10 \%$ and $15 \%$ test level, respectively. As we fixed the organizational variables over time (see Section 4.2), we cannot identify the direct effect of organizational capital in our framework that controls for firm fixed effects. 


\section{FIGURES}

Figure 1: Contrasting the aggregated and the disaggregated perspective of complementarities between ICT and organizational capital
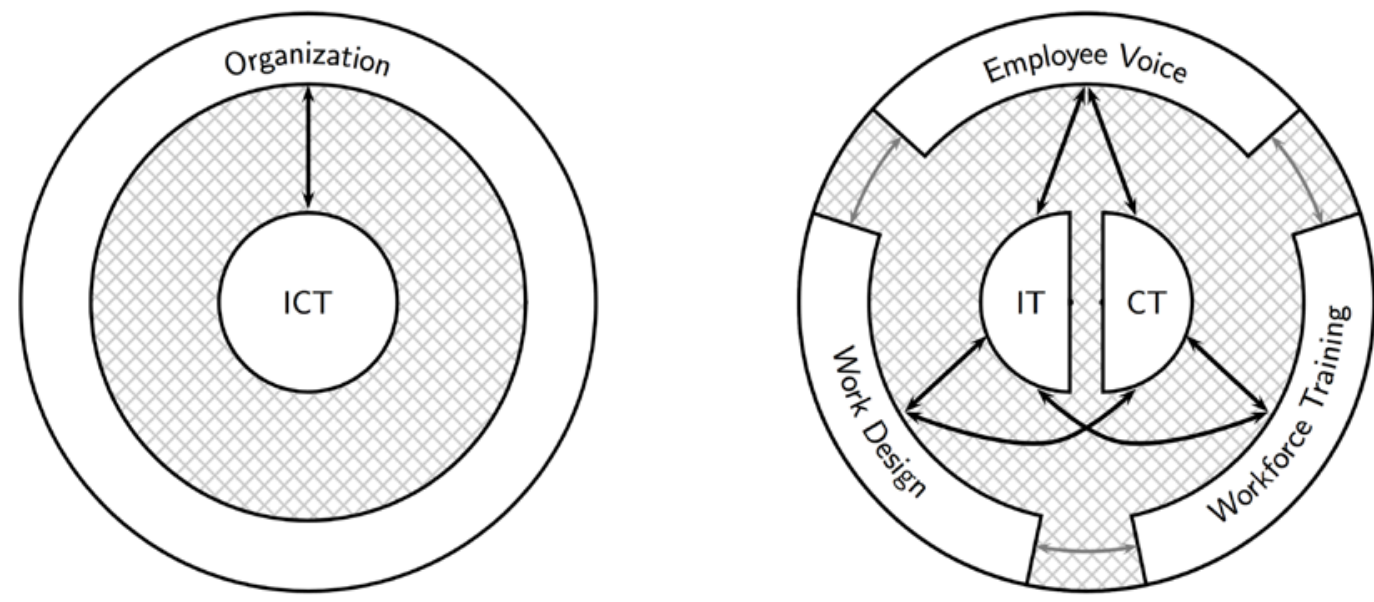
Figure 2: Interaction effects as average marginal effects

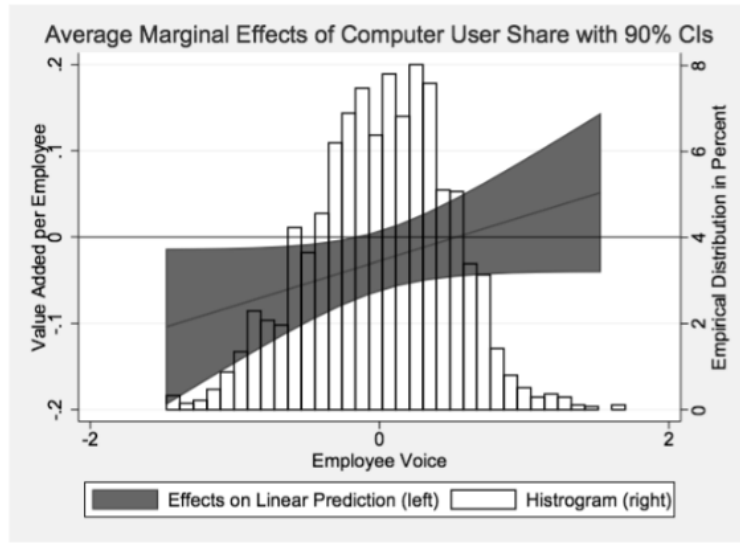

(a): Employee Voice and IT

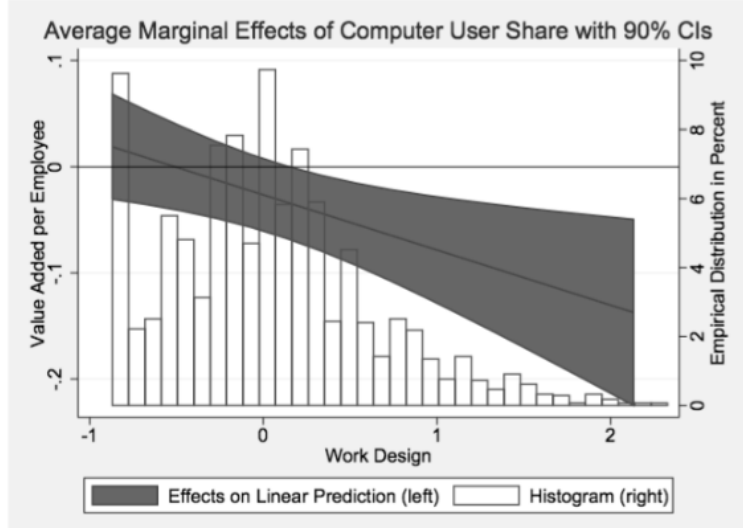

(c): Work Design and IT

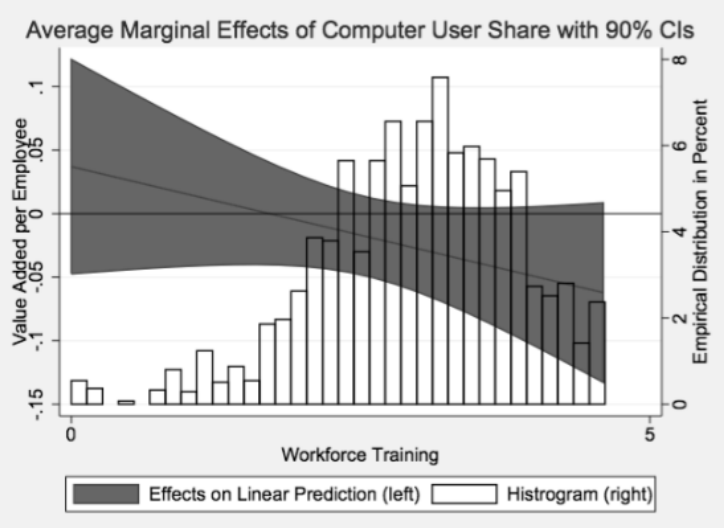

(e): Workforce Training and IT

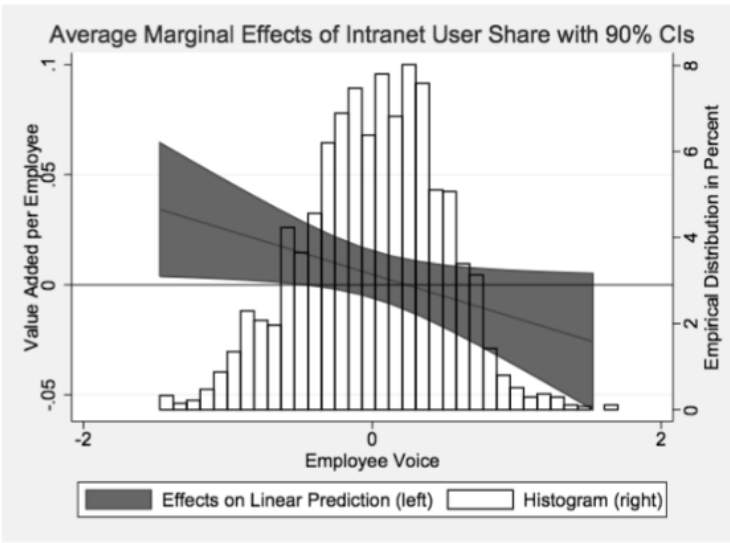

(b): Employee Voice and CT

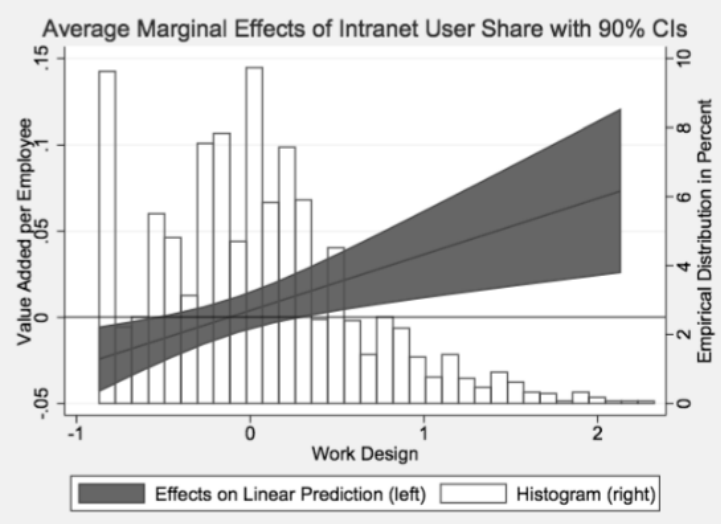

(d): Work Design and CT

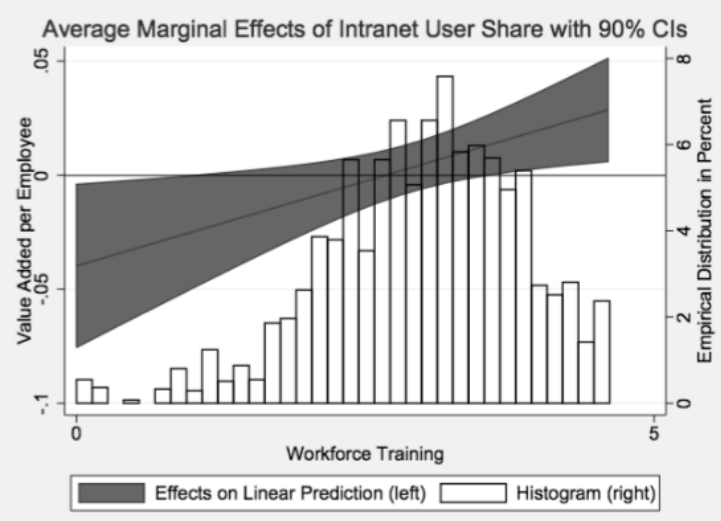

(f): Workforce Training and CT 


\section{APPENDIX}

Table A.1: Descriptive statistics based on main model (Column 3 of Table 3; N=2743)

\begin{tabular}{lcccc} 
Variable & Mean & Std. Dev. & Min & Max \\
\hline value_added_per_employee & 223389.8 & 1525362 & 203.9462 & $7.70 \mathrm{e}+07$ \\
computer_user_share & 51.02807 & 29.68287 & 0 & 90 \\
intranet_user_share & 34.92891 & 33.7027 & 0 & 90 \\
employee_voice & .0048315 & .4809734 & -1.472656 & 1.700468 \\
workforce_training & 30.24632 & 22.051 & 0 & 100 \\
work_design & .0201474 & .5889207 & -.8692163 & 2.325401 \\
employment_number & 411.9529 & 2281.753 & 20 & 45271 \\
tertiary_share & 20.84069 & 17.76768 & 0 & 100 \\
r\&d_expenditures & 4604.858 & 15309.89 & 0 & 274261.6 \\
non_ICT_investment & 21864.14 & 262298.6 & 0 & $1.19 \mathrm{e}+07$ \\
foreign_owned & .1917608 & .3937577 & 0 & 1 \\
price_competition_intensity & 3.994167 & .9786016 & 1 & 5 \\
non_price_competition_intensity & 3.098806 & .9508932 & 1 & 5 \\
\hline
\end{tabular}

Table A.2: Correlation matrix based on main model (Column 3 of Table 3; N=2743)

\begin{tabular}{|c|c|c|c|c|c|c|}
\hline & $\begin{array}{l}\text { value_added_ } \\
\text { per_employee }\end{array}$ & $\begin{array}{c}\text { computer_user } \\
\text { share }\end{array}$ & $\begin{array}{l}\text { intranet_- } \\
\text { user_share }\end{array}$ & $\begin{array}{l}\text { employee_ } \\
\text { voice }\end{array}$ & $\begin{array}{c}\text { workforce_ } \\
\text { training }\end{array}$ & $\begin{array}{l}\text { work_ } \\
\text { design }\end{array}$ \\
\hline computer_user_share & 0.3557 & & & & & \\
\hline intranet_user_share & 0.2839 & 0.5251 & & & & \\
\hline employee_voice & 0.2669 & 0.3699 & 0.2938 & & & \\
\hline workforce_training & 0.2352 & 0.3453 & 0.2792 & 0.2915 & & \\
\hline work_design & 0.1076 & 0.1808 & 0.2106 & 0.1237 & 0.2437 & \\
\hline employment_number & 0.1228 & 0.1355 & 0.3215 & 0.1927 & 0.1333 & 0.1719 \\
\hline tertiary_share & 0.3038 & 0.4529 & 0.3272 & 0.2418 & 0.2826 & 0.1828 \\
\hline r\&d_expenditures & 0.1290 & 0.2081 & 0.1599 & 0.1407 & 0.0681 & 0.2652 \\
\hline non_ICT_investment & 0.1575 & 0.0091 & 0.0417 & 0.0585 & 0.0878 & 0.0712 \\
\hline foreign_owned & 0.1775 & 0.2171 & 0.2105 & 0.1168 & 0.0806 & 0.1115 \\
\hline price_competition_intensity & -0.0565 & -0.0053 & 0.0051 & -0.0346 & -0.0148 & 0.0640 \\
\hline \multirow[t]{2}{*}{ non_price_competition_intensity } & 0.1122 & 0.1533 & 0.0686 & 0.1111 & 0.0602 & 0.0843 \\
\hline & $\begin{array}{l}\text { value_added_- } \\
\text { per_employee }\end{array}$ & $\begin{array}{c}\text { computer_user } \\
\text { share }\end{array}$ & $\begin{array}{l}\text { intranet_- } \\
\text { user_share }\end{array}$ & $\begin{array}{l}\text { employee_ } \\
\text { voice }\end{array}$ & $\begin{array}{c}\text { workforce_ } \\
\text { training }\end{array}$ & $\begin{array}{l}\text { work_ } \\
\text { design }\end{array}$ \\
\hline computer_user_share & 0.3557 & & & & & \\
\hline
\end{tabular}


Technological and Organizational Capital

intranet_user_share

employee_voice

workforce_training

work_design

employment_number

tertiary_share

r\&d_expenditures

non_ICT_investment

foreign_owned

price_competition_intensity

non_price_competition_intensity
$0.2839 \quad 0.5251$

$\begin{array}{lll}0.2669 & 0.3699 & 0.2938\end{array}$

$\begin{array}{llll}0.2352 & 0.3453 & 0.2792 & 0.2915\end{array}$

$\begin{array}{lllll}0.1076 & 0.1808 & 0.2106 & 0.1237 & 0.2437\end{array}$

$\begin{array}{llllll}0.1228 & 0.1355 & 0.3215 & 0.1927 & 0.1333 & 0.1719\end{array}$

$\begin{array}{llllll}0.3038 & 0.4529 & 0.3272 & 0.2418 & 0.2826 & 0.1828\end{array}$

$\begin{array}{llllll}0.1290 & 0.2081 & 0.1599 & 0.1407 & 0.0681 & 0.2652\end{array}$

$\begin{array}{llllll}0.1575 & 0.0091 & 0.0417 & 0.0585 & 0.0878 & 0.0712\end{array}$

$\begin{array}{llllll}0.1775 & 0.2171 & 0.2105 & 0.1168 & 0.0806 & 0.1115\end{array}$

$\begin{array}{llllll}-0.0565 & -0.0053 & 0.0051 & -0.0346 & -0.0148 & 0.0640\end{array}$

$\begin{array}{llllll}0.1122 & 0.1533 & 0.0686 & 0.1111 & 0.0602 & 0.0843\end{array}$

\begin{tabular}{|c|c|c|c|c|c|c|}
\hline & $\begin{array}{c}\text { employment } \\
\text { number }\end{array}$ & $\begin{array}{c}\text { tertiary } \\
\text { share }\end{array}$ & $\begin{array}{c}r_{\text {expenditure }} \\
\text { s }\end{array}$ & $\begin{array}{c}\text { non_ICT_ } \\
\text { investmen } \\
t\end{array}$ & $\begin{array}{c}\text { foreign } \\
- \\
\text { owned }\end{array}$ & $\begin{array}{c}\text { price_competition } \\
- \\
\text { intensity }\end{array}$ \\
\hline tertiary_share & 0.1239 & & & & & \\
\hline r\&d_expenditures & 0.1594 & 0.2480 & & & & \\
\hline non_ICT_investment & 0.1627 & 0.0401 & 0.1340 & & & \\
\hline foreign_owned & 0.1073 & 0.1371 & 0.1122 & -0.0682 & & \\
\hline price_competition_intensity & 0.0128 & -0.0249 & 0.0151 & -0.0659 & 0.0322 & \\
\hline non_price_competition_intensity & 0.0765 & 0.0810 & 0.1867 & 0.0110 & 0.1177 & 0.0275 \\
\hline
\end{tabular}


Table A.3: Testing alternative model specifications

\begin{tabular}{|c|c|c|c|c|c|c|}
\hline & (1) & $(2)$ & (3) & (4) & (5) & (6) \\
\hline & \multicolumn{6}{|c|}{ value_added_per_employee } \\
\hline \multirow[t]{2}{*}{ computer_user_share } & 0.027 & & 0.039 & 0.036 & & 0.049 \\
\hline & (0.048) & & (0.049) & (0.048) & & (0.049) \\
\hline \multirow{2}{*}{ employee_voice*computer_user_share } & $0.051^{\dagger}$ & & $0.067^{* *}$ & $0.058^{*}$ & & $0.073^{* *}$ \\
\hline & $(0.033)$ & & $(0.030)$ & $(0.032)$ & & $(0.031)$ \\
\hline \multirow[t]{2}{*}{ workforce_training*computer_user_share } & -0.011 & & -0.015 & -0.012 & & -0.017 \\
\hline & $(0.016)$ & & $(0.018)$ & $(0.017)$ & & $(0.018)$ \\
\hline \multirow[t]{2}{*}{ work_design*computer_user_share } & -0.005 & & -0.029 & -0.008 & & $-0.035+$ \\
\hline & $(0.021)$ & & $(0.023)$ & $(0.021)$ & & $(0.023)$ \\
\hline \multirow[t]{2}{*}{ intranet_user_share } & & -0.011 & -0.018 & & -0.011 & -0.019 \\
\hline & & $(0.023)$ & $(0.024)$ & & $(0.024)$ & $(0.025)$ \\
\hline \multirow[t]{2}{*}{ employee_voice*intranet_user_share } & & -0.016 & $-0.024 \dagger$ & & -0.011 & -0.020 \\
\hline & & $(0.016)$ & $(0.016)$ & & $(0.016)$ & $(0.015)$ \\
\hline \multirow[t]{2}{*}{ workforce_training*intranet_user_share } & & 0.005 & 0.007 & & 0.005 & 0.008 \\
\hline & & (0.008) & (0.009) & & $(0.008)$ & $(0.009)$ \\
\hline \multirow[t]{2}{*}{ work_design*intranet_user_share } & & $0.029 * *$ & $0.032 * *$ & & $0.031^{* *}$ & $0.034 * * *$ \\
\hline & & $(0.012)$ & $(0.013)$ & & $(0.012)$ & $(0.013)$ \\
\hline \multirow[t]{2}{*}{ employment_number } & $-0.271 * * *$ & $-0.277^{* * *}$ & $-0.276 * * *$ & $-0.271 * * *$ & $-0.278^{* * *}$ & $-0.277^{* * *}$ \\
\hline & $(0.085)$ & $(0.085)$ & $(0.085)$ & $(0.087)$ & $(0.086)$ & $(0.086)$ \\
\hline \multirow[t]{2}{*}{ tertiary_share } & -0.012 & -0.014 & -0.013 & -0.017 & -0.017 & -0.018 \\
\hline & $(0.018)$ & (0.019) & $(0.018)$ & $(0.018)$ & (0.019) & $(0.018)$ \\
\hline \multirow[t]{2}{*}{ r\&d_expenditures } & -0.002 & -0.003 & -0.003 & -0.002 & -0.003 & -0.003 \\
\hline & $(0.005)$ & $(0.005)$ & $(0.005)$ & $(0.005)$ & $(0.005)$ & $(0.005)$ \\
\hline \multirow[t]{2}{*}{ non_ICT_investment } & 0.010 & 0.010 & 0.010 & 0.009 & 0.008 & 0.008 \\
\hline & $(0.007)$ & $(0.007)$ & $(0.007)$ & $(0.008)$ & $(0.008)$ & $(0.008)$ \\
\hline \multirow[t]{2}{*}{ foreign_owned } & 0.055 & 0.049 & 0.054 & 0.059 & 0.058 & 0.061 \\
\hline & $(0.049)$ & $(0.049)$ & $(0.049)$ & $(0.051)$ & $(0.051)$ & $(0.051)$ \\
\hline \multirow[t]{2}{*}{ price_competition_intensity } & $-0.016+$ & $-0.017+$ & $-0.016+$ & $-0.017+$ & $-0.018^{+}$ & $-0.017+$ \\
\hline & $(0.011)$ & $(0.011)$ & $(0.011)$ & $(0.011)$ & $(0.011)$ & $(0.011)$ \\
\hline \multirow[t]{2}{*}{ non_price_competition_intensity } & -0.000 & -0.001 & -0.001 & -0.002 & -0.002 & -0.002 \\
\hline & $(0.011)$ & $(0.011)$ & $(0.011)$ & (0.011) & $(0.011)$ & $(0.011)$ \\
\hline \multirow[t]{2}{*}{ outsourcing } & & & & -0.008 & -0.009 & -0.008 \\
\hline & & & & $(0.027)$ & $(0.027)$ & $(0.026)$ \\
\hline \multirow[t]{2}{*}{ takeover } & & & & 0.016 & 0.017 & 0.017 \\
\hline & & & & $(0.025)$ & $(0.025)$ & $(0.025)$ \\
\hline \multirow[t]{2}{*}{ merger } & & & & 0.002 & 0.001 & -0.002 \\
\hline & & & & $(0.030)$ & $(0.030)$ & $(0.030)$ \\
\hline \multirow[t]{2}{*}{ sale_of_division } & & & & 0.004 & 0.005 & 0.006 \\
\hline & & & & $(0.030)$ & $(0.030)$ & $(0.030)$ \\
\hline \multirow[t]{2}{*}{ _cons } & $13.305^{* * *}$ & $13.325^{* * *}$ & $13.332^{* * *}$ & $13.307^{* * *}$ & $13.343^{* * *}$ & $13.337 * * *$ \\
\hline & $(0.432)$ & $(0.426)$ & $(0.430)$ & $(0.443)$ & $(0.438)$ & $(0.441)$ \\
\hline Firm fixed effects & yes & yes & yes & yes & yes & yes \\
\hline Time fixed effects & yes & yes & yes & yes & yes & yes \\
\hline Industry-time fixed effects & no & no & no & no & no & no \\
\hline $\mathrm{N}$ & 2743 & 2743 & 2743 & 2692 & 2692 & 2692 \\
\hline Groups & 1282 & 1282 & 1282 & 1279 & 1279 & 1279 \\
\hline R2 within & 0.03 & 0.04 & 0.04 & 0.03 & 0.04 & 0.04 \\
\hline Log Likelihood & -282.44 & -278.93 & -276.28 & -267.66 & -264.14 & -261.26 \\
\hline
\end{tabular}

Notes: see Table 2 for the variable definitions; standard errors that are robust to heteroskedasticity and clustered at the firm level (clustered sandwich estimator) are in brackets under the coefficients; $* * *, * *, *,+$ denote statistical significance at the $1 \%, 5 \%, 10 \%$ and $15 \%$ test level, respectively. As we fixed the organizational variables over time (see Section 4.2), we cannot identify the direct effect of organizational capital in our framework that controls for firm fixed effects. 


\section{Table A.4: Allow organizational variable to vary over time}

\begin{tabular}{|c|c|}
\hline & value_added_per_employee \\
\hline \multirow[t]{2}{*}{ computer_user_share } & 0.024 \\
\hline & $(0.034)$ \\
\hline \multirow[t]{2}{*}{ employee_voice*computer_user_share } & 0.027 \\
\hline & $(0.023)$ \\
\hline \multirow[t]{2}{*}{ workforce_training*computer_user_share } & -0.017 \\
\hline & $(0.011)$ \\
\hline \multirow[t]{2}{*}{ work_design*computer_user_share } & $-0.039 * *$ \\
\hline & $(0.017)$ \\
\hline \multirow[t]{2}{*}{ intranet_user_share } & -0.036 \\
\hline & $(0.023)$ \\
\hline \multirow[t]{2}{*}{ employee_voice*intranet_user_share } & $-0.020 *$ \\
\hline & $(0.012)$ \\
\hline \multirow[t]{2}{*}{ workforce_training*intranet_user_share } & $0.014^{*}$ \\
\hline & $(0.008)$ \\
\hline \multirow[t]{2}{*}{ work_design*intranet_user_share } & $0.017^{* *}$ \\
\hline & $(0.008)$ \\
\hline \multirow[t]{2}{*}{ employee_voice } & -0.059 \\
\hline & $(0.077)$ \\
\hline \multirow[t]{2}{*}{ workforce_training } & 0.037 \\
\hline & $(0.034)$ \\
\hline \multirow[t]{2}{*}{ work_design } & $0.111^{* *}$ \\
\hline & $(0.052)$ \\
\hline \multirow[t]{2}{*}{ cons } & $13.260 * * *$ \\
\hline & $(0.412)$ \\
\hline Control variables & yes \\
\hline Firm fixed effects & yes \\
\hline Industry-time fixed effects & yes \\
\hline $\mathrm{N}$ & 2743 \\
\hline Groups & 1282 \\
\hline R2 within & 0.19 \\
\hline
\end{tabular}

Notes: see Table 2 for the variable definitions; standard errors that are robust to heteroskedasticity and clustered at the firm level (clustered sandwich estimator) are in brackets under the coefficients; $* * *, * *, *,+$ denote statistical significance at the $1 \%, 5 \%, 10 \%$ and $15 \%$ test level, respectively. The control variables are the same as in the model of column 3 of Table 3 (i.e., employment_number, tertiary_share, r\&d_expenditures, non_ICT_investment, foreign_owned, price_competition_intensity, non_price_competition_intensity). 
Table A.5: Test interactions individually

\begin{tabular}{|c|c|c|c|c|c|c|}
\hline & (1) & (2) & (3) & (4) & (5) & (6) \\
\hline & & & value_added_ & er_employe & & \\
\hline computer_user_share & -0.023 & -0.006 & -0.017 & & & \\
\hline & $(0.017)$ & $(0.043)$ & $(0.017)$ & & & \\
\hline employee_voice*computer_user_share & 0.024 & & & & & \\
\hline & (0.029) & & & & & \\
\hline workforce_training*computer_user_share & & -0.004 & & & & \\
\hline & & $(0.016)$ & & & & \\
\hline work_design*computer_user_share & & & $-0.031+$ & & & \\
\hline & & & $(0.021)$ & & & \\
\hline intranet_user_share & & & & 0.003 & $-0.033^{*}$ & 0.002 \\
\hline & & & & $(0.006)$ & (0.019) & $(0.006)$ \\
\hline employee_voice*intranet_user_share & & & & -0.005 & & \\
\hline & & & & $(0.011)$ & & \\
\hline workforce_training*intranet_user_share & & & & & $0.012^{*}$ & \\
\hline & & & & & $(0.006)$ & \\
\hline work_design*intranet_user_share & & & & & & $0.025^{* *}$ \\
\hline & & & & & & $(0.011)$ \\
\hline _cons & $12.856^{* * *}$ & $13.395^{* * *}$ & $13.498 * * *$ & $13.202^{* * *}$ & $13.244^{* * *}$ & $13.384 * * *$ \\
\hline & $(0.418)$ & $(0.333)$ & $(0.348)$ & $(0.387)$ & $(0.365)$ & $(0.370)$ \\
\hline Control variables & yes & yes & yes & yes & yes & yes \\
\hline Firm fixed effects & yes & yes & yes & yes & yes & yes \\
\hline Industry-time fixed effects & yes & yes & yes & yes & yes & yes \\
\hline $\mathrm{N}$ & 4191 & 4361 & 4211 & 3977 & 4129 & 3996 \\
\hline Groups & 2556 & 2638 & 2556 & 2482 & 2555 & 2479 \\
\hline R2 within & 0.17 & 0.16 & 0.17 & 0.18 & 0.17 & 0.18 \\
\hline
\end{tabular}

Notes: see Table 2 for the variable definitions; standard errors that are robust to heteroskedasticity and clustered at the firm level (clustered sandwich estimator) are in brackets under the coefficients; $* * *, * *, *,+$ denote statistical significance at the $1 \%, 5 \%, 10 \%$ and $15 \%$ test level, respectively. The control variables are the same as in the model of column 3 of Table 3 (i.e., employment_number, tertiary_share, r\&d_expenditures, non_ICT_investment, foreign_owned, price_competition_intensity, non_price_competition_intensity). 
Table A.6: Test subcategories of overall organizational variables

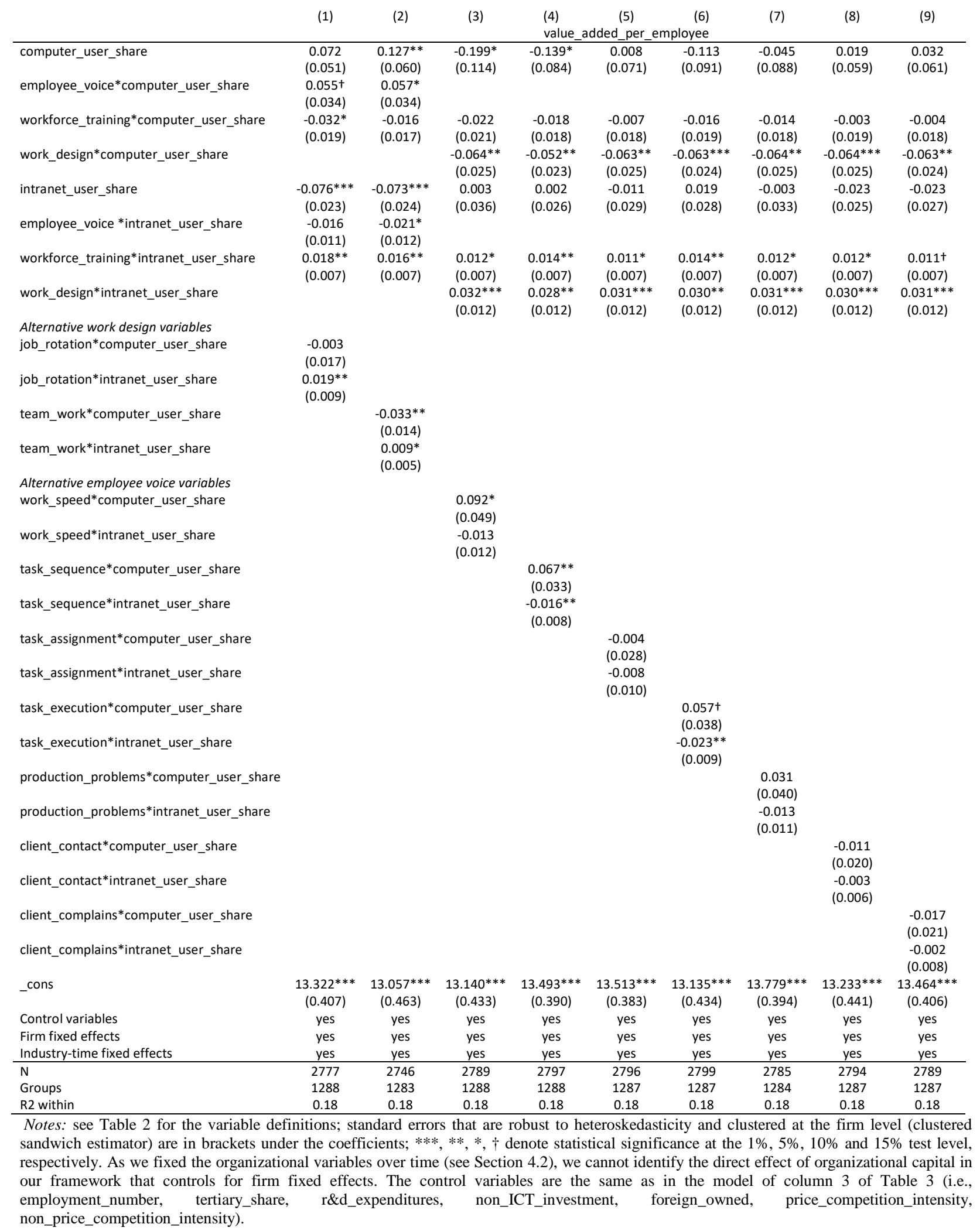


Table A.7: Test direct measures for IT usage
(1)
(2)
(3)
(4)

(5)

\begin{tabular}{|c|c|c|c|c|c|}
\hline \multirow{2}{*}{ IT_intensity } & \multicolumn{5}{|c|}{ value_added_per_employee } \\
\hline & $\begin{array}{l}-0.033 \\
(0.054)\end{array}$ & & & & \\
\hline employee_voice *IT_intensity & $\begin{array}{c}0.019 \\
(0.029)\end{array}$ & & & & \\
\hline workforce_training*IT_intensity & $\begin{array}{c}0.010 \\
(0.017)\end{array}$ & & & & \\
\hline work_design*IT_intensity & $\begin{array}{l}-0.043 \\
(0.031)\end{array}$ & & & & \\
\hline ERP_usage & & $\begin{array}{l}-0.131 \\
(0.095)\end{array}$ & $\begin{array}{l}-0.026 \\
(0.039)\end{array}$ & & \\
\hline employee_voice *ERP_usage & & $\begin{array}{l}-0.013 \\
(0.068)\end{array}$ & $\begin{array}{c}0.005 \\
(0.065)\end{array}$ & & \\
\hline workforce_training*ERP_usage & & $\begin{array}{c}0.034 \\
(0.029)\end{array}$ & & & \\
\hline work_design*ERP_usage & & $\begin{array}{l}-0.022 \\
(0.074)\end{array}$ & & & \\
\hline CRM_usage & & & & $\begin{array}{l}-0.041 \\
(0.131)\end{array}$ & \\
\hline employee_voice *CRM_usage & & & & $\begin{array}{c}0.026 \\
(0.048)\end{array}$ & \\
\hline workforce_training*CRM_usage & & & & $\begin{array}{c}0.022 \\
(0.040)\end{array}$ & \\
\hline work_design*CRM_usage & & & & $\begin{array}{l}-0.052 \\
(0.046)\end{array}$ & \\
\hline SCM_usage & & & & & $\begin{array}{c}0.030 \\
(0.149)\end{array}$ \\
\hline employee_voice *SCM_usage & & & & & $\begin{array}{c}0.077 \\
(0.078)\end{array}$ \\
\hline workforce_training*SCM_usage & & & & & $\begin{array}{l}-0.017 \\
(0.045)\end{array}$ \\
\hline work_design*SCM_usage & & & & & $\begin{array}{l}-0.154^{*} \\
(0.089)\end{array}$ \\
\hline _cons & $\begin{array}{c}13.303^{* * *} \\
(0.484)\end{array}$ & $\begin{array}{c}13.305^{* * *} \\
(0.490)\end{array}$ & $\begin{array}{c}13.293 * * * \\
(0.489)\end{array}$ & $\begin{array}{c}13.278 * * * \\
(0.497)\end{array}$ & $\begin{array}{c}13.308^{* * *} \\
(0.483)\end{array}$ \\
\hline Control variables & yes & yes & yes & yes & yes \\
\hline Firm fixed effects & yes & yes & yes & yes & yes \\
\hline Industry-time fixed effects & yes & yes & yes & yes & yes \\
\hline $\mathrm{N}$ & 2738 & 2738 & 2738 & 2738 & 2738 \\
\hline Groups & 1300 & 1300 & 1300 & 1300 & 1300 \\
\hline R2 within & 0.16 & 0.16 & 0.16 & 0.16 & 0.16 \\
\hline
\end{tabular}

Notes: see Table 2 for the variable definitions; standard errors that are robust to heteroskedasticity and clustered at the firm level (clustered sandwich estimator) are in brackets under the coefficients; ***, **, *, † denote statistical significance at the $1 \%, 5 \%, 10 \%$ and $15 \%$ test level, respectively. As we fixed the organizational variables over time (see Section 4.2), we cannot identify the direct effect of organizational capital in our framework that controls for firm fixed effects. The control variables are the same as in the model of column 3 of Table 3 (i.e., employment_number, tertiary_share, r\&d_expenditures, non_ICT_investment, foreign_owned, price_competition_intensity, non_price_competition_intensity). 
Table A.8: Test different time windows

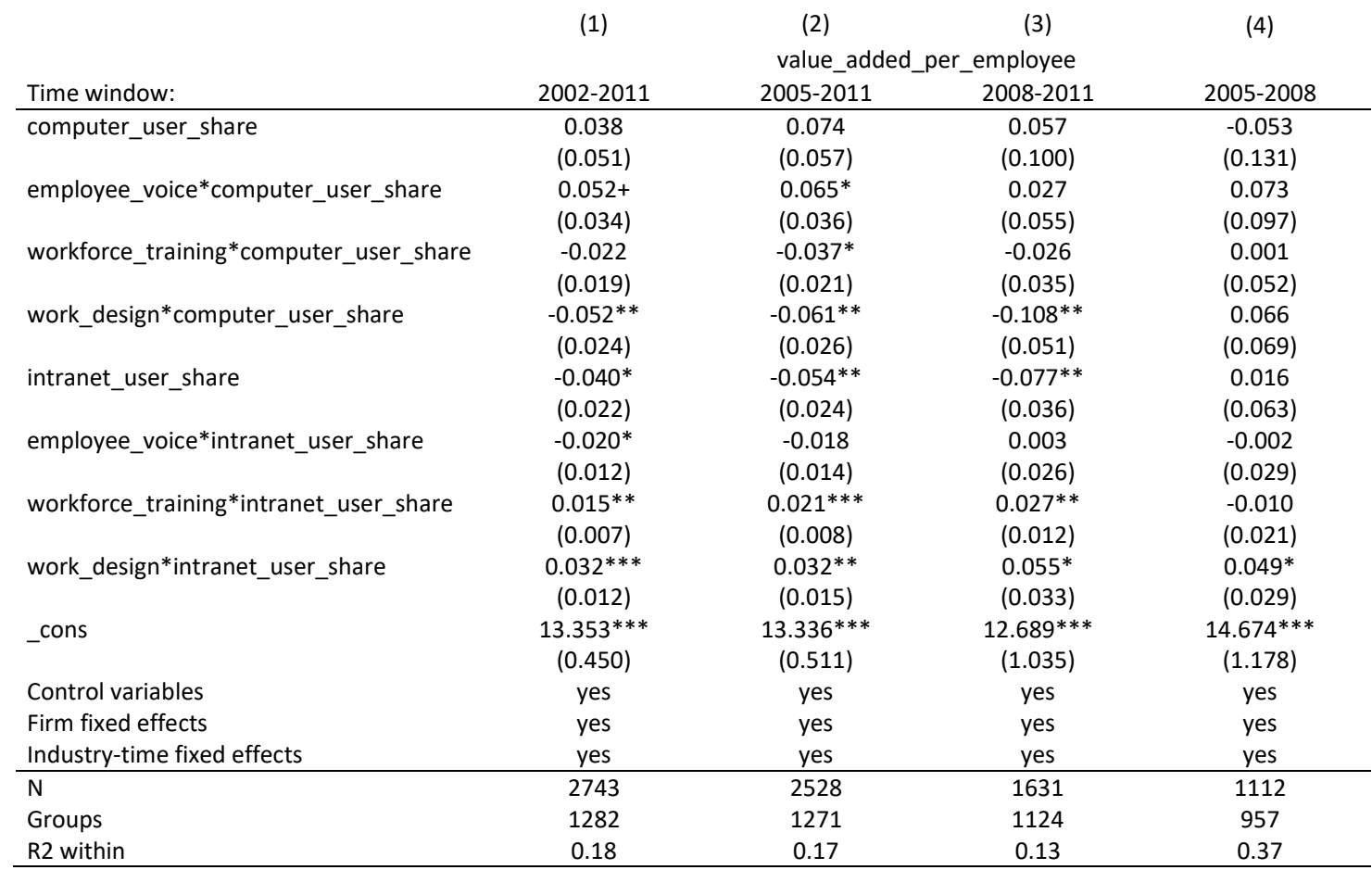

Notes: see Table 2 for the variable definitions; standard errors that are robust to heteroskedasticity and clustered at the firm level (clustered sandwich estimator) are in brackets under the coefficients; ***, **, *, † denote statistical significance at the $1 \%, 5 \%, 10 \%$ and $15 \%$ test level, respectively. As we fixed the organizational variables over time (see Section 4.2), we cannot identify the direct effect of organizational capital in our framework that controls for firm fixed effects. The control variables are the same as in the model of column 3 of Table 3 (i.e., employment_number, tertiary_share, r\&d_expenditures, non_ICT_investment, foreign_owned, price_competition_intensity, non_price_competition_intensity).

Table A.9: Factor analysis: rotated factor loadings and unique variance

\begin{tabular}{lccccc} 
& Factor 1 & Factor 2 & Factor 3 & Factor 4 & Factor 5 \\
\hline work_speed & 0.7334 & 0.0946 & 0.0017 & 0.0344 & -0.0711 \\
task_sequence & 0.7399 & 0.2254 & -0.0215 & 0.1041 & 0.0350 \\
task_assignment & 0.5348 & 0.3172 & 0.0081 & -0.0095 & 0.1494 \\
task_execution & 0.7322 & 0.1134 & 0.0209 & 0.0531 & 0.0275 \\
production_problems & 0.3834 & 0.4566 & -0.0054 & 0.0692 & 0.0761 \\
client_contact & 0.1652 & 0.8383 & -0.0207 & 0.1129 & -0.0145 \\
client_complains & 0.1198 & 0.8806 & -0.0286 & 0.0330 & 0.0654 \\
job_rotation & -0.0371 & -0.2289 & 0.0467 & 0.5706 & 0.4392 \\
team_work & 0.0703 & 0.1795 & 0.2232 & 0.6958 & 0.0364 \\
workforce_training & 0.1378 & 0.1921 & 0.0027 & 0.6961 & -0.2073 \\
delayering & 0.0297 & 0.0862 & 0.0505 & -0.0312 & 0.8700 \\
individual_performance_salary & 0.0352 & -0.0920 & 0.7136 & 0.0631 & -0.0803 \\
group_performance_salary & -0.0261 & 0.0244 & 0.7868 & 0.1166 & 0.0677 \\
firm_performance_salary & -0.0004 & -0.0228 & 0.7943 & 0.0194 & 0.0804 \\
\hline Statistics & & & & & \\
Kaiser-Meyer-Olkin measure: & 0.7594 & & & & 0.0751 \\
Proportion of variance: & 0.1517 & 0.1427 & 0.1297 & 0.0962 & 1.01017 \\
Eigenvalue: & 3.13526 & 1.99131 & 1.14022 & 1.05953 & 1.964 \\
\hline
\end{tabular}

